\title{
Exploration of Ethnobotanical and Ethnomedicinal Importance of Naturally Growing Plants of District Neelum From Areas of Dawarian to Ratti Gali, Azad Jammu and Kashmir
}

\author{
Muhammad Ajaib \\ Mirpur University of Science and Technology \\ ishtiaq muhammad ( $\sim$ drishtiaqajk@gmail.com ) \\ Mirpur University of Science and Technology https://orcid.org/0000-0003-2468-1413 \\ Mehwish Maqbool \\ Mirpur University of Science and Technology \\ Tanveer Hussain \\ Mirpur University of Science and Technology
}

Khizar Hayat Bhatti

University of Gujrat

Rafiq Khan

Ministry of Environment

Abdul Ghani

University of Sargodha

Waheeda Mushtaq

Mirpur University of Science and Technology

lqbal Hussain

Government College University Faisalabad

Muhammad Azeem

Government College University Faisalabad

Shazia Khatoon

University of Kotli Azad Jammu and Kashmir

\section{Research}

Keywords: Ethnobotanical study, Wild plants, Statistical tools, Spearman's rank correlation, Allium griffithianum, Ethnopharmacological analysis

Posted Date: November 24th, 2020 
DOI: https://doi.org/10.21203/rs.3.rs-103983/v1

License: (c) (1) This work is licensed under a Creative Commons Attribution 4.0 International License. Read Full License 


\title{
Exploration of ethnobotanical and ethnomedicinal importance of naturally growing plants of District Neelum from areas of Dawarian to Ratti Gali, Azad Jammu and Kashmir
}

\begin{abstract}
Muhammad Ajaib $^{1}$, Muhammad Ishtiaq ${ }^{1 *}$, Mehwish Maqbool ${ }^{1}$, Tanveer Hussain ${ }^{1}$, Sardar Rafiq Khan ${ }^{2}$, Khizat Hayat Bhatti ${ }^{3}$, Abdul Ghani ${ }^{4}$, Waheeda Mushtaq1, Iqbal Hussain ${ }^{5}$, Muhamnad Azeem ${ }^{5}$, Shahzia Khatoon ${ }^{6}$
\end{abstract}

1. Deaprtment of Botany, Mirpur University of Science and Technology (MIUST), Mirpur, 10250, AJK, Pakistan

2. Deparment of Environment Protection, Govt of AJK Muzaffarabad, Pakistan

3. Deptt of Botany, University of Gujrat, Pakistan

4. Deptt of Botany, University of Sargodha, Pakistan

5. Department of Botany, Government College University, Faisalabad, Pakistan

6. Deptt of Botany Univ of Kotli, AJK, Pakistan

\begin{abstract}
Background: Ethnobotanical study was continued from old civilization to date. Kashmir covered with $46 \%$ vagatation and out of these many are naturally growing plants. Many areas are still unexplored the plants ethnomedicinal inportanmce of wild plants. In this regard, ethnobotanical survey on the unexplored area of District Anthmaqam, Azad Jummu \& Kashmir was conducted for identification of wild plants and their ethnomedical values.

Methods: The current research work was carried out by interviewing the local peoples through a questionnaire method. Data analysis was done by different novel statistical tools such as fidelity level (FL), Spearman's rank correlation (SRC), informant consensus factor (ICF) and direct matrix ranking (DMR) strategies. The ethnobotanical uses of many wild plants were correlated with the plants who already used by societies in some countries of the world. But few plants are used as medicines only indigenous peoples and we reccomented these plants for peoples in other parts of countery as well as throughout the world in future.
\end{abstract}

Results: Peoples used plants in daily life as in form of vegetables, fodder, fuel, timber as well as for medicinal purposes. Indegeneous peoples are using many types of wild plants to cure different diseases like asthma, dysentery, constipation, cold, fever, joint pain, wound healing, kidney 
infection and many types of skin diseases. Current study revealed on 103 plants species belonging to 46 plant families from selected area of District Neelum, Azad Jammu and Kashmir. It was observed that Asteraceae with 12 plants species was the the most prominant family occurs in the study area. Out of 103 plants, $75.72 \%$ have single-usage, $20.38 \%$ have dual-usages and $3.88 \%$ have multiple-usage. Among plant partused, leaves having the highest percentage (34\%) that are used by people of the study area for the treatment of different diseases followed by the root $25.2 \%$. Powdered is the dosage form having highest percentage $38 \%$ followed by juice and mixture with $29 \%$ and $13 \%$, respectively. Some plants used as fodder having highest percentage $37 \%$ followed by Food (vegetables and fruits) with 32\%. Construction having lowest percentage with $6 \%$. Different statistical tools were applied for more consize results elaboration as mentioned in method section. Data analysis through FL depicted that Allium griffithianum and Adiantum aethiopicum have highest fidelity level of $75 \%$ followed by the Mentha longifolia with fedility level of about $72 \%$. The highest ICF value for recorded for ear-ache and house-thatching $(0.91)$ followed by the construction (0.89) while the lowest ICF value recorded for fodder (0.03) followed by blood purification (0.5). Spearman's rank correlation test confirmed that the number of uses of plants increases with the increase in the number of species.

Conclusions: The present research focused to explore the uses of plants in different purposes by experience of old peoples in the study area. Ethnobotanical research focused to explore the uses of plants in different purposes by experience of old peoples in the study area. Young gereration of the area did not know ethnobotanical importance of wild plants in the area. So, this study will be useful those peoples and researchers in different fields such as ethnopharmacology, agriculture and biotechnology for future work.

Keyworks: Ethnobotanical study, Wild plants, Statistical tools, Spearman's rank correlation, Allium griffithianum, Ethnopharmacological analysis

Correspondance: drishtiaqajk@gmail.com

\section{Background}

The ethnobotany came into being when earliest man observed animal intake various plants, assembled and alarmed for his food and for fixing his lesion. Ethnobotany plays a significant role between biology, social and traditional system [1,2]. It was observed that indigenous plants related 
knowledge has been continued from one generation to other generation and so on through experience of local peoples. The knowledge of rural areas peoples is best example and key of ethnobotanical study of plants [3]. This study of ethnobotany provides better uses of plants in the field of ethnomedicines as well as it includes use of plants for medicines, food, rituals, social life and others fields of human socities This multi-discipilanary connection between human societies and plants isn't restricted to the utilization of plants for attire, food and asylum yet in addition remembers their utilization for different fields as; strict functions, decorative purposes and medical services [4].

Plants are widely used by every type of community as medicines, whether directly as tribe recipes or medication of different indigenous schemes. There is critical necessity of supporting the medicinal plants that are over collected so that, coming future generations could advantage from these valuable plants that are actual gift of nature for the mankind. The indigenous ethnomedicinal value of plants is helpful to different fields of botany as in the field of Taxonomy, Ecology, Pharmacology and Wildlife in civilizing the prosperity of an area, besides highlightening the traditional uses [5].

The specific plants are used for particular ethnic aims and on particular occasions by cultural groups throughout the existence [6]. It was assessed that $25 \%$ drugs are integrated from restorative plants and right around $80 \%$ people groups of creating nations are still relies upon conventional and local prescriptions to fix ailments as well as fundamental medical services [7].

In our neighbouring country, 27 plant species are used traditionally as ethnomedicinal plants which belong to 18 different taxonomic families for the treatment of different diseases and ailments. The green parts of plants (leaves) are used most frequently and many types of medicines are manufactured in the form of paste and administrative orally [8].

The therapeutic uses of plants have been verified by using informents agreement factor (ICF) values and it was explored that some medicinal plants were used to treat jungle fever (0.71), jaundice (0.62), urological issues (0.56), dermatological issues (0.45), torment (0.30) and respiratory turmoil (0.33), and keeping in mind that the overall wellbeing (0.15) and gastrointestinal issues classification (0.28) [9]. 
Greater part of therapeutic plants might be utilized as a wash to shower the body with less meds being ingested. Before the advancement of current pipes innovation, clean water was not so much accessible but rather more valuable. In such conditions, it might be favorable for washing to happen less as often as possible yet with the utilization of therapeutic plants. Lab testing of a considerable lot of the therapeutic plants utilized by the Tiwi have discovered them to have against microbial properties. Customarily the utilization of such plants are accepted to have happened regularly in a similar way that food plants were gathered.

All necessary requirements of life from medicine to shelter and food to fibre are gained from forests' vegetation. [10]. If the processing of raw woodland material which produce wood, branches, logs and fibres for creating differnet merchandise that had been useful in every day life for sustainable livelihood [11].

It was estimated that 2500 plant species are recommended internationally as medicinal puspose. The percentage of use value of medicinal plants ranges betwwen $4-20 \%$ in different countries of the world. Similarly, it was observed pabout 6000 higher plant species are used for medicinal purposes in diferent locations, their falls betwwen $10-30 \%$ of the flora of Pakistan. The use of medicinal plants is very important in rural and tribal areas of Pakistan where as it is considered as inicial treatment against different diseases remidies [12].

Some therapeutic plants are financial and utilized in treatment of certain sicknesses. An aggregate of 59 plants species were utilized for fourteen distinct classifications of illnesses, for example, skin ailment. Restorative greenery, for example, Berberis lyceum, Ajuga bracteosa, Aconitum heterophyllum, Bistorta amplexicaule, Saussurea lapa and Jurinea dolomiaea are on the edge of eradication due to over misuse [13].

The ethnomedicinal information were accumulated from various region of Punjab Pakistan through polls and broad individual discoursed with local people including 40 guys 20 females of different age bunches between 50 to 80 years and furthermore dark-striped cats and hakims. Around 40 plant species having a place with 22 families were explored which are used by local individuals to fix issues and sicknesses, for example, asthma, ulcer, gonorrhea, heaps, stomach agony, and skin illnesses. The outcomes exhibited that the zone is wealthy in vegetation yet remained organically unexplored [14]. 
The ethnobotanical concentrates on trees of region Kotli, Azad Kashmir uncovered conventional use of 50 tree spp., having a place with 39 genera and 24 families with Moraceae, the most well-known family having 9 species. The regular use of tree was restorative, fuel and grain. The phonological examinations uncovered that $65 \%$ of the species bloomed from the period of August forward or in winter season [15].

The ethnobotanical assessment on the restorative plants of Darguti, Tehsil Khuiratta, Azad Jammu and Kashmir was perceived during 2014-2015 by meeting the neighborhood occupants through a poll. A sum of 100 plant species having a place with 47 families were reported. It was noticed that individuals utilize plants as vegetables and grain, fuel just as therapeutic commitments. Neighborhood individuals use treatment of various ailments like lockjaw, diabetes, looseness of the bowels, asthma, kidney contamination, clogging, gastric ulcer, bronchial illnesses, gonorrhea, scabies, throat aggravation and numerous sorts of skin maladies with nearby plants [16].

The utilization of customary ethnomedicinal by the nearby seniors of Area Mirpur Azad Jammu and Kashmir saw by mehmood and his partners. Ethnomedicinal information was gathered by mean of poll strategy, meets and direct perception. An aggregate of 38 plant species having a place with 22 families were accounted for of hurling ethnomedicinal use. About 13 hakims and 78 local people were visited to collect ethnomedicinal data [2]. The ethnobotanical estimations of the most normally utilized plants of the Neelum Valley AJ\&K, investigated and gives an account of the indigenous information on various networks of the examination zone [17].

The State of Azad Jammu and Kashmir (AJ\&K) is declared as diverse habitats, variable climatic conditions and appropriate fertile soil with rich nutrients [18-19]. It has variety of natural resources particularly rich in medicinal plant flora [20]. The state of AJK has a wide range of mountainous ecosystems which are affluent in flora and fauna. The area of Azad Kashmir has scrub forest, alpine and grasslands ecosystem as vegetational catogeries. Anthropogenic and other natural hazerds depicted a high effect on the ecosystems of the areas [21].

The examination zone "Neelum Valley" is arranged North-East of Muzaffarabad at an elevation of 900-6325 meters above ocean level. It lies between $73^{\circ}-75^{\circ} \mathrm{E}$ longitude and $32^{\circ}-35^{\circ}$ $\mathrm{N}$ scope [22]. It is the biggest vale of Azad Jammu and Kashmir (AJ\&K) covering a territory of $3737 \mathrm{Km}$. Dawarian town is arranged at $110 \mathrm{~km}$ north of the capital Muzaffarabad and is around 
$5299 \mathrm{ft}$ over the ocean level. The atmosphere is calm with freezing winters (normal $0-4{ }^{\circ} \mathrm{C}$ ) and moderate summers (normal temperature $20-30{ }^{\circ} \mathrm{C}$ ). Normal precipitation is $1650 \mathrm{~mm}$ yearly. The territory has different sorts of landforms and little levels. Soil is loamy and sandy topsoil, fit for holding dampness and great development of woodlands. Larger part of the region is secured with thick vegetation and woods trees [23]. The sampling site "Ratti Gali" is situated at $19 \mathrm{~km}$ from Dawarian and is about $12130 \mathrm{ft}$ above the sea level. It lies between $74^{\circ}-76^{\circ} \mathrm{E}$ longitude and $34^{\circ}$ $36^{\circ} \mathrm{N}$ latitude [22]. Vegetation mainly consist of herbs and shrubs with some tree species. Ratti Gali is famous place because of lake know as Ratti Gali lake which is an alpine glacial lake. The territory has inadequately evolved street and other foundation. Principle crops incorporate corn (Zea mays L.), turnip (Brasica rapa L.), and bean (Phaseolus vulgaris L.) in a coordinated framework. A high extent of nearby individuals are related with animals [24].

Many plant species used as ethomedicines in different areas of AJ\&K. The older indigenous peoples of Azad Kashmir have more ethnobotanical knowledge of plant species as comparison to younger ones [24]. However, the current research area is rarely reported except few plant species. Many species of the study were unexplored and reported first time in this paper. Therefore, the present research paper was focused on social and geographical characteristics of different study sites. Then all types of plants were collected for identification, preservation and exposed their ethnobotanical uses. To document the indigenous knowledge of wild plant from Dowariyan and Rati Gali. To explore the indeginous use of plants by local communities. Other key medicinal values and differernt perspectives for better livelihood were also observed and highlighted. Floristic composition of various species compiled for further novel and authentic ethnobotanical exploration. All data was analysed by different statistical tools for more accurate and significant assessment of all identified plant species with special reference to ethnomedicinal importance from the selected study area of District Atmokam, Azad Kashmir, Pakistan and their future perspective as for pharmaceutical analysis. The research will also assist in conservation of the precious medicinal flora of the area. 


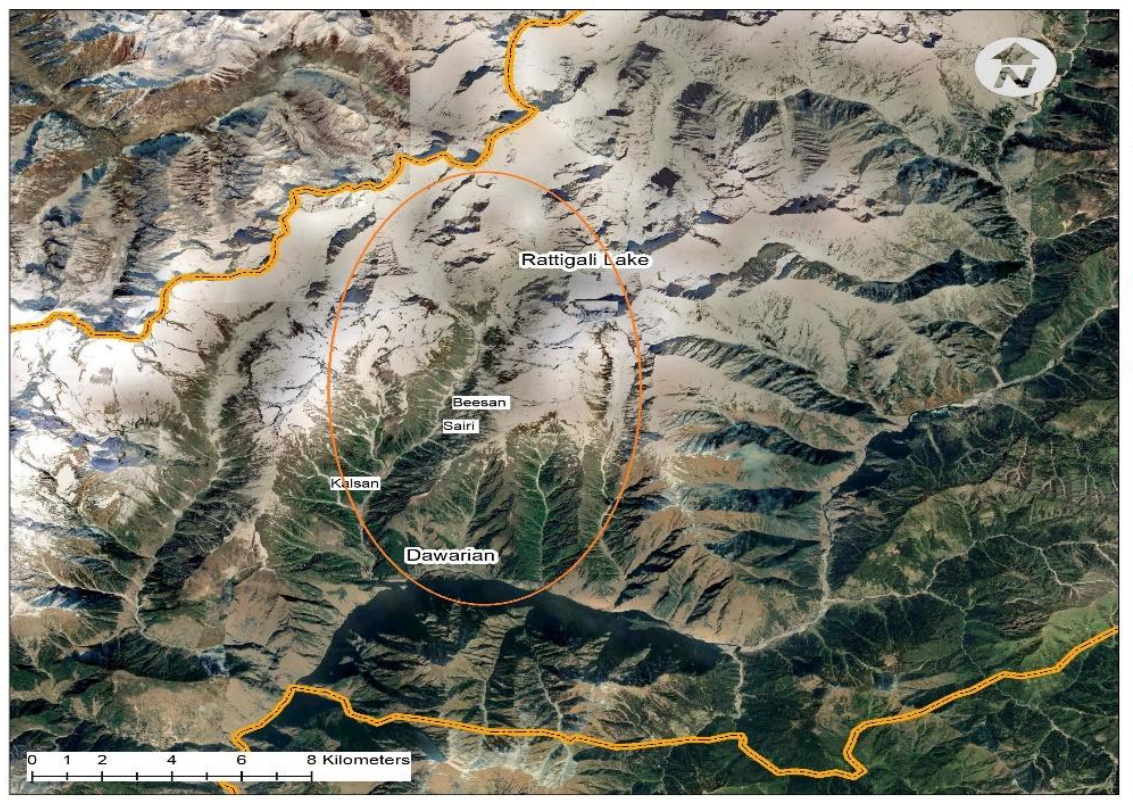

Overview Maps:

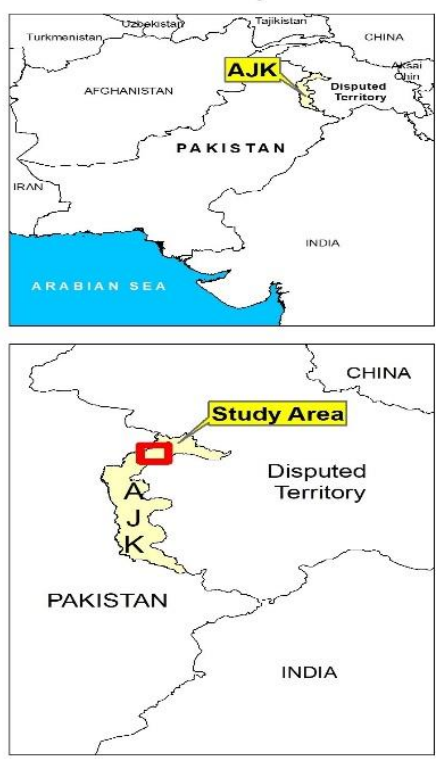

Map of the study area that indicated study sites in circle

\section{Meterials and methods}

The current ethnobotanical analysis was conducted during the year 2019 from Dawarian to Rati Gali sites of District Athmaqam Neelum Valley, Azad Jammu and Kashmir.

\section{Ethnobotanical information collection}


Ethnobotanical informations were gathered from the local peoples of the study area by random visits with help of local guide or translator. The data collected from the local people indicate local name, local uses, recipe, part used, occurrence, characters involved in the collection, marketing and other related information. The plants of Dawarian and Rati Gali District Athmaqam Neelum valley were categorized according to their economic value such as medicinal, fodder, vegetable, thatching and fuel wood etc. through meeting poll from various individuals however inclination was given to neighborhood senior individuals, who had a ton of data about the plants and their customary employments. Survey and observations added more information in literature [24]. Various age bunches were perceived and organized based on 10 years' age contrast. The 6070 age bunch was more educated therefore close to home understanding.

\section{Data collection by questionnaire method}

For obtaining our concerned objectives questionnaire method using open and close-ended interview was applied to extract useful data from the local people and herbalists. About 40 informants were interviewed of both the genders randomly for obtaining ethnobotanical data. Our informants consist of local people. Informants were asked about the plants they used in the treatment of different ailments. The interviewer also briefed us that how a particular plant is used, its dosage form, its part used and also the recipe of plant used for the treatment of certain diseases [25]. In the open-ended interviews, people were allowed to speak openly about the plants used for the treatment of different diseases. The researcher interviewed the people in their local language so as to extract allmost and reliable information from the people following protocol of Thompson [25] with some modifications.

\section{Plant samples collection and identification}

The plant examples were gathered from the study zone. They were dried, squeezed and mounted appropriately and submitted in Herbarium, (MUH). MUST, Bhimber Campus, AJ\&K with voucher numbers for additional reference. They were related to the assistance of vegetation of Pakistan [19] and properly identified plants were kept for future reference.

\section{Data analysis}


Data analysis was conducted by using different qunantitative ethnobotanical tools. The dependability and legitimacy of ethnobotanical research work and data was checked and upheld by calculating informant consensus factor (ICF), fidelity level (FL) and Family index (FI) and spearman's rank correlation followed by previous botanists [26, 27].

\section{Fidelity level (FL)}

The fidelity level (FL) is the level of witnesses guaranteeing the utilization of certain plant for a similar object, was determined for the most habitually revealed by usage or ailments as:

$$
\mathrm{FL}(\%)=\mathrm{Np} / \mathrm{N} \times 100
$$

Where, Np indicated the number of informants that claim a use of plant species used for a particular purpose/ disease, and $\mathrm{N}$ is mentioned the number of informants that use the plant as a medicine to treat any given disease. This statistical tool was also applied by Farooq and his group [26].

\section{Informants consensus factor (ICF)}

ICF identifies the agreement of the informants on the reported medicines for the group of ailments. It was calculated by the following equation:

$$
\mathrm{ICF}=\text { nur }-\mathrm{nt} / \text { nur }-1
$$

Where nur $=$ number of used citation in each category and $n t=$ number of specie used. This method is used for further examinations in drug investigation and other exploration ventures [28].

\section{Family index (FL)}

Family index is also calculated to check the member of which family is mostly used to cure against different diseases [13].

\section{Direct Matrix Ranking (DMR)}


Direct matrix ranking was applied which depicts populace thickness of plant species and their protection status in the investigation territory. DMR depicts highest biotic pressure on the plants which are most commonly used by the local people in the investigated area for the treatment of various ailments [24].

\section{Spearman's correlation test}

In spearman's rank correlation, analysis was calculated about indigenous knowledge of male and female to find out the fact that whether male have better knowledge than female or not as well as to explore correlation of number of uses with number of plants. It was proved that the number of uses of plants also increases as the number of plants species increases. It is calculated as:

$$
r_{s}=1-6\left[\frac{\sum d^{2}}{n\left(n^{2}-1\right)}\right]
$$

Where $d^{2}$ is the square of the sum of the ranks and $\mathrm{n}$ is the number of informants [29].

\section{Results and discussion}

The present ethnobotanical examination persual generated a checklist of plants of Dawarian and Rati Gali, District Athmaqam, Azad Jammu and Kashmir, Pakistan. In this study, some medicinal plants were explored first time from the study area occurring at high elevated sites for detailed phytochemical and ethnopharmaceutical research point of view. Ethnobotanical as well as ethnomedicinal explorations were also elaborated in consise form after identification of each plant species. Individuals of the examination territory generally use plants and trees for different purposes such as fodder, wood, medicine, food and other purposes.

In the recent study it is observed and investigated that the local community of study areas used wild plant species for fulfillment of their daily life needs such as medicines, as food/vegetables, silage for animals, for fuel use and to making household tools and construct their houses. Local people of area collect the medicinal plants and used them for various ailments for

human being as well as to cure the many diseases of their domestic animals. Berberis lycium, Oxyria digyna, Aconogonon alpinum were most important plants in the study area. Local community of study areas $90 \%$ depends on the livestock as the source of income. Similar studies on the plant species of Neelum Valley, Azad Jammu and Kashmir, Pakistan were documented by 
Mahmood and his research group [17]. In which 40 plant species having a place with 31 families were discovered to be important for therapeutic, food, grain/scavenge, fuel, lumber, cover and farming purposes. Neighborhood individuals utilized indigenous plants for their basic ailments. e.g., Berberis lycium, Podophyllum hexandrum, Oxyria digyna, Rheum austral, Aconogonon alpinum, Angelica cyclocarpa and Geranium wallichianum were most important plants from the study area.

The Table 1 indicated 6 social comparisons between two observed sites names as Dawarian and Rati Gali prior to plants collection and identification for ethnomedicinal study. These characters' observation directly correlates with plants distribution in the study area. It was observed that more families (52), number of informants (12), average number of families (15-8) and livestock dependence (90\%) maximum in Dawarian site as comparison to Rati Gali. These findings were indicated that less number of plants and their minimum diversity appeared Dawarian site. These findings were strongly supported by some ethnobotanist who conducted research on this and orther allied areas of AJK [24, 28].

Table 1: Social characteristics of the variable samples between two study sites: Ratia Galli and Dewarian of Dist. Atmaqam of Azad Jammu and Kashmir

\begin{tabular}{|l|l|l|l|}
\hline S.No & Social characteristics & Dawarian & Rati Gali \\
\hline 1 & number of families & 52 & 8 \\
\hline 2 & number of informants & 12 & 5 \\
\hline 3 & Reliance on livestock as an income source & $90 \%$ & $30 \%$ \\
\hline 4 & Average age of informants & $70-50$ & $40-30$ \\
\hline 5 & Average number of family members & $15-8$ & $10-3$ \\
\hline 6 & Migration ratio & $70 \%$ & $100 \%$ \\
\hline
\end{tabular}

Different geographic characteristics like topography, area climates, population size, altitude/elevation and vegetation size were measured in Table 2. It was obsereved that Dawarian has 1615 feet altitude while Rati Gali present at 3700 feet hight. This huge elevation difference showed diversity in geographic charateristics [22].

Table 2 Geographical characteristics observation of the two study sites: Ratia Galli and Dewarian of Dist. Atmaqam of Azad Jammu and Kashmir 


\begin{tabular}{|l|l|l|l|}
\hline S. No. & Sites & $\begin{array}{l}\text { Elevation } \\
(\mathbf{m})\end{array}$ & Geographical characteristics \\
\hline 1 & Dawarian & 1,615 & $\begin{array}{l}\text { The village has very fertile soil and thick vegetation. } \\
\text { Village has ever green thick forest of Pinus wallichiana. It } \\
\text { is mountainous area. Population of the village is small } \\
\text { sized but the area is huge. }\end{array}$ \\
\hline 2 & Rati Gali & 3,700 & $\begin{array}{l}\text { This area is located at high altitude. Vegetation mainly } \\
\text { consist of herbs or shrubs. There is very low population } \\
\text { but area is huge. People migrates here with their domestic } \\
\text { animals in summers from different areas. }\end{array}$ \\
\hline
\end{tabular}

\section{Plants collection, identification and preservation}

The plants were gathered from the selected towns of District Atmakam, AJK. The plants were identified mainly with the help of Flora of Pakistan. The specimens were submitted in Herbarium, Department of Botany, MUST, Bhimber Campus with voucher numbers for further reference. Family-wise inventory of the plants was given in Table 3. Total 103 plants were identified from the study area with their family names, habit observed (herb, shrub or tree) and local name of each plant elaborated in the Table 3. Similar findings were counted by other taxonomists in other countries [30].

Table 3 Family-wise Inventory of some plants of Dawarian to Ratti Gali, District Athmaqam

\section{Azad Jammu and Kashmir}

\begin{tabular}{|c|c|c|c|c|c|}
\hline $\begin{array}{l}\text { Sr. } \\
\text { No. }\end{array}$ & Family & $\begin{array}{l}\text { Sr. } \\
\text { No. }\end{array}$ & Species & Habit & Local name \\
\hline \multirow[t]{12}{*}{1} & Astraceae & 1 & Achillea millefolium $\mathrm{L}$. & Herb & Gandana \\
\hline & & 2 & Artemisia japonica Thunb. & Herb & Chaou \\
\hline & & 3 & Anaphalis triplinervis Clarke & Herb & Butt mehndi \\
\hline & & 4 & Artemisia macrophylla Fisch. ex Besser & Herb & Chita chaou \\
\hline & & 5 & Gerbera gossypina (Royle) Beauverd & Herb & Kofe \\
\hline & & 6 & Ligularia thomsonii (Clarke) Pojark. & Herb & Jungli surajmukh \\
\hline & & 7 & Matricaria chamomilla $\mathrm{L}$. & Herb & Tamak boti \\
\hline & & 8 & Saussurea lappa (Decne.) Sch.Bip. & Herb & Khut \\
\hline & & 9 & Cirsium arvense (L.) Scop. & Herb & Jungli kandyara \\
\hline & & 10 & Sonchus asper $(\mathrm{L}$.$) Hill$ & Herb & Dhodal \\
\hline & & 11 & Senecio chrysanthemoides DC. & Herb & Chir hand \\
\hline & & 12 & Solidago virgaurea $\mathrm{L}$. & Herb & Pinja phool \\
\hline 2 & Amaryllidaceae & 13 & Allium griffithianum Boiss. & Herb & Jungli pyaz \\
\hline 3 & Araceae & 14 & Arisaema tortuosum (Wall.) Schott & Herb & Sanp ki boti \\
\hline 4 & Aquifoliaceae & 15 & Ilex dipyrena Wall. & Tree & Kandaro \\
\hline 5 & Anacardiaceae & 16 & Rhus succedanea $\mathrm{L}$. & Tree & Alkhal \\
\hline
\end{tabular}




\begin{tabular}{|c|c|c|c|c|c|}
\hline \multirow[t]{3}{*}{6} & Berberidaceae & 17 & Berberis lycium Royle & Shrub & Sumbal \\
\hline & & 18 & Podophyllum hexandrum Royle & Shrub & Ban kukri \\
\hline & & 19 & Podophyllum emodi Wall. ex Hook.f. \& Thomson & Shrub & Tra patra \\
\hline 7 & Buddlejaceae & 20 & Buddleja crispa Benth. & Shrub & Gansu \\
\hline \multirow[t]{2}{*}{8} & Buxaceae & 21 & Buxus wallichiana Baill. & Herb & Chiriri \\
\hline & & 22 & Sarcococca saligna Müll.Arg. & Shrub & Shangal \\
\hline \multirow[t]{2}{*}{9} & Boraginaceae & 23 & Cynoglossum lanceolatum Forssk. & Herb & Chiro \\
\hline & & 24 & Onosma bracteata Wall. & Herb & Gao zuban \\
\hline 10 & Betulaceae & 25 & Corylus colurna $\mathrm{L}$. & Tree & Aurni \\
\hline \multirow[t]{2}{*}{11} & Brassicaceae & 26 & Erysimum hieraciifolium L. f. & Herb & Mirchi \\
\hline & & 27 & Erysimum hedgeanum Al-Shehbaz & Herb & Maneera \\
\hline \multirow[t]{2}{*}{12} & Convolvulaceae & 28 & Convolvulus arvensis $\mathrm{L}$. & Herb & Berrhi \\
\hline & & 29 & Cuscuta reflexa Roxb. & Herb & Neela tari \\
\hline 13 & Campanulaceae & 30 & Campanula pallida Wall. & Herb & Bikh \\
\hline 14 & Colchicaceae & 31 & Colchicum luteum Baker & Herb & Sorinjan \\
\hline 15 & Celastraceae & 32 & Euonymus hemsleyanus Loes. & Tree & Seeki \\
\hline 16 & Crassulaceae & 33 & Hylotelephium ewersii (Ledeb.) H.Ohba & Herb & Loon salooni \\
\hline 17 & Cupressaceae & 34 & Juniperus communis $\mathrm{L}$. & Tree & Bentheri \\
\hline \multirow[t]{3}{*}{18} & Caprifoliaceae & 35 & Morina persica $\mathrm{L}$. & Herb & Bekh-e-Akwar \\
\hline & & 36 & Valeriana jatamansi Jones & Herb & Panchi hola \\
\hline & & 37 & Viburnum cotinifolium D. Don & Shrub & Ukloo \\
\hline 19 & Caryophyllaceae & 38 & Silene vulgaris (Moench) Garcke & Herb & Murkun \\
\hline \multirow[t]{2}{*}{20} & Fumariaceae & 39 & Corydalis govaniana Wall. & Herb & Bhutkas \\
\hline & & 40 & Corydalis vaginans Royle & Herb & Mameri \\
\hline \multirow[t]{2}{*}{21} & Geraniaceae & 41 & Geranium rotundifolium $\mathrm{L}$. & Herb & Ratan jut \\
\hline & & 42 & Geranium villosum Ten. & Herb & Gull-e-attar \\
\hline 22 & Gentianaceae & 43 & Swertia paniculata Wall. & Herb & Charyta \\
\hline
\end{tabular}




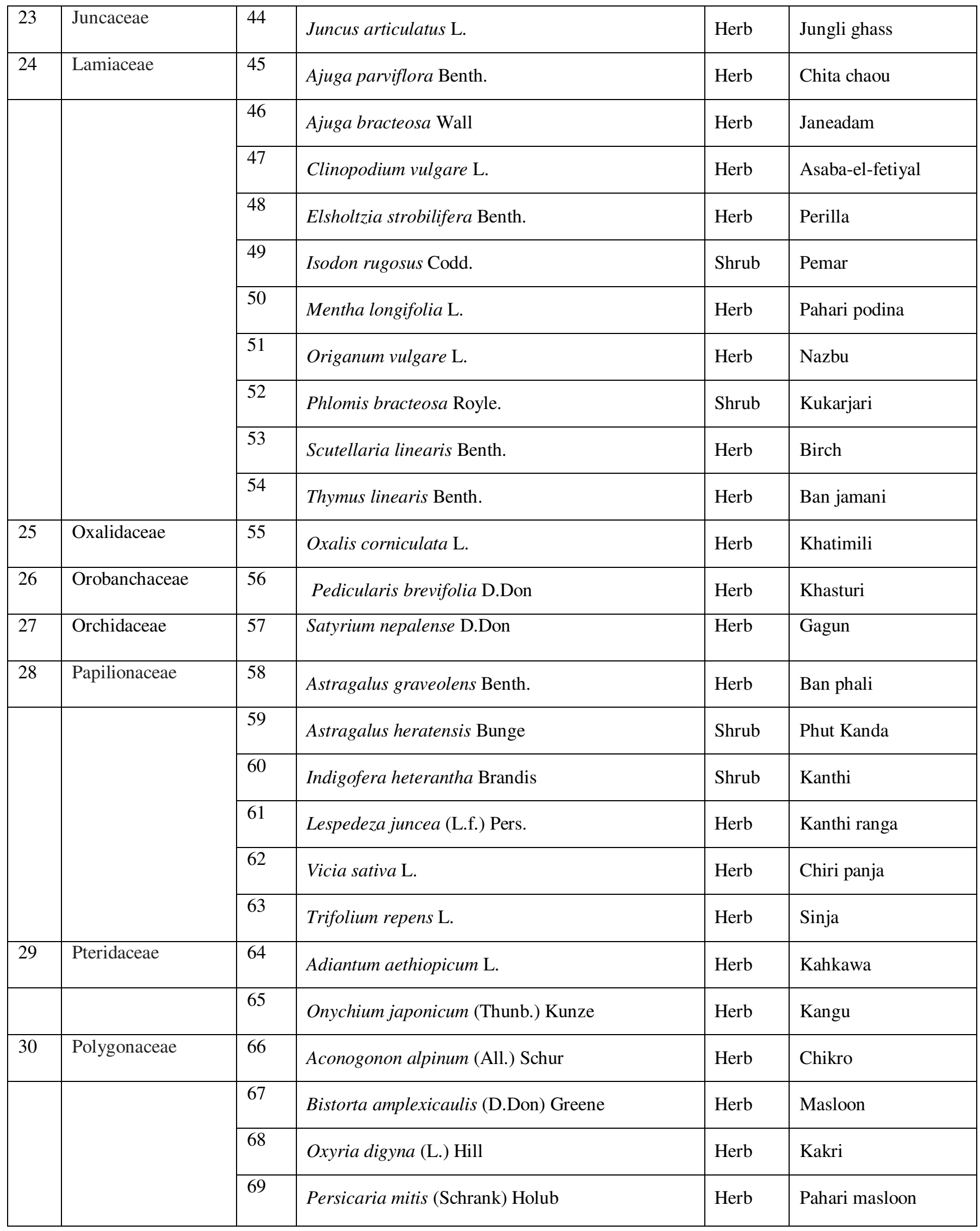




\begin{tabular}{|c|c|c|c|c|c|}
\hline & & 70 & Rheum emodi Wall. & Herb & Chit patra \\
\hline & & 71 & Rheum australe D. Don & Herb & Chutyal \\
\hline 31 & Polygalaceae & 72 & Polygala chinensis L. & Herb & Sanp ki jari \\
\hline 32 & Pinaceae & 73 & Abies pindrow Royle & Tree & Partal \\
\hline & & 74 & Cedrus deodara Don & Tree & Davdaar \\
\hline & & 75 & Pinus wallichiana Jacks. & Tree & Kayal \\
\hline & & 76 & Pinus roxburghii Sarg. & Tree & Cheer \\
\hline & & 77 & Picea smithiana (Wall.) Boiss. & Tree & Kachal \\
\hline 33 & Poaceae & 78 & Bromus pectinatus Thunb. & Herb & Pero \\
\hline & & 79 & Cenchrus pennisetiformis Steud. & Herb & Lidder \\
\hline & & 80 & Digitaria cruciata (Nees) A.Camus & Herb & Ghaa \\
\hline & & 81 & Sorghum halepense (L.) Pers. & Herb & Baru \\
\hline 34 & Primulaceae & 82 & Primula denticulata $\mathrm{Sm}$. & Herb & Mamera \\
\hline 35 & Plantaginaceae & 83 & Plantago lanceolata $\mathrm{L}$. & Herb & Kala chamchi part \\
\hline & & 84 & Wulfenia amherstiana Benth. & Herb & ------------ \\
\hline 36 & Ranunculacea & 85 & Actaea spicata $\mathrm{L}$. & Herb & Moneeri \\
\hline & & 86 & Aconitum heterophyllum Wall. ex Royle & Herb & Ptrees \\
\hline & & 87 & Caltha alba Cambess. & Herb & Makanpath \\
\hline 37 & Rosaceae & 88 & Cotoneaster microphyllus Wall. ex Lindl. & Herb & Loni \\
\hline & & 89 & Rosa microphylla Roxb. ex Lindl. & Shrub & Shigari \\
\hline & & 90 & Rubus niveus subsp. horsfieldii (Miq.) Focke & Shrub & Pakana \\
\hline & & 91 & Fragaria nubicola (Lindl.) Lacaita & Herb & Mehwa \\
\hline 38 & Rutaceae & 92 & Skimmia laureola Franch. & Shrub & Neri \\
\hline 39 & Sapindaceae & 93 & Acer cappadocicum Gled. & Tree & Tera Kanna \\
\hline & & 94 & Aesculus indica Hook. & Tree & Ban khaur \\
\hline
\end{tabular}




\begin{tabular}{|l|l|l|l|l|l|}
\hline 40 & Saxifragaceae & 95 & Bergenia ciliata Sternb. & Herb & Betbewa \\
\hline 41 & Sabiaceae & 96 & Meliosma simplicifolia Walp. & Shrub & Bakhaish \\
\hline 42 & Salicaceae & 97 & Populus alba L. & Tree & Sufaida \\
\hline & & 98 & Salix tetrasperma Roxb. & Tree & Bheens \\
\hline 43 & Symplocaceae & 99 & Symplocos paniculata (Thunb.) Miq. & Shrub & Ludder \\
\hline 44 & Taxaceae & 100 & Taxus baccata L. & Tree & Thuni \\
\hline 45 & Violaceae & 101 & Viola biflora L. & Herb & Phul naqsh \\
\hline 46 & Viscaceae & 103 & Viscum album L. & Herb & Thandi jari \\
\hline
\end{tabular}

\section{Ethnobotanical data of wild plants}

Ethnobotanical data of wild plants including voucher number, local names, botanical family, parts used, gathering period and traditional uses were compiled in Table 4. Among them Asteraceae having $12(11.65 \%)$ species, Lamiaceae having 9 (8.73\%) whereas Polygonaceae having $7(6.79 \%)$ species, respectively. Papilionaceae having $6(5.82 \%)$ species. Poaceae and Rosaceae each having 4 (3.88\%) species while Berberidaceae, Caprifoliaceae and Ranunculaceae each having $3(2.91 \%)$ species. Buxaceae, Boraginaceae, Brassicaceae, Convolvulaceae, Fumariaceae, Geraniaceae, Pteridaceae, Plantaginaceae, Spindaceae, Salicaceae and Violaceae each having 2 (1.94\%) species., Amaryllidaceae, Araceae, Aquifoliaceae, Buddlejaceae, Butelaceae, Campanulaceae, Colchicaceae, Celastraceae, Crassulaceae, Cupressaceae, Caryophyllaceae, Gentianaceae, Juncaceae, Oxalidaceae, Orobanchaceae, Orchidaceae, Primulaceae, Rutaceae, Saxifragaceae, Sabiaceae, Symplocaceae, Taxaceae and Viscaceae each having $1(0.97 \%)$ species. A pie-chart of all families having number of species given in (Fig.1). 


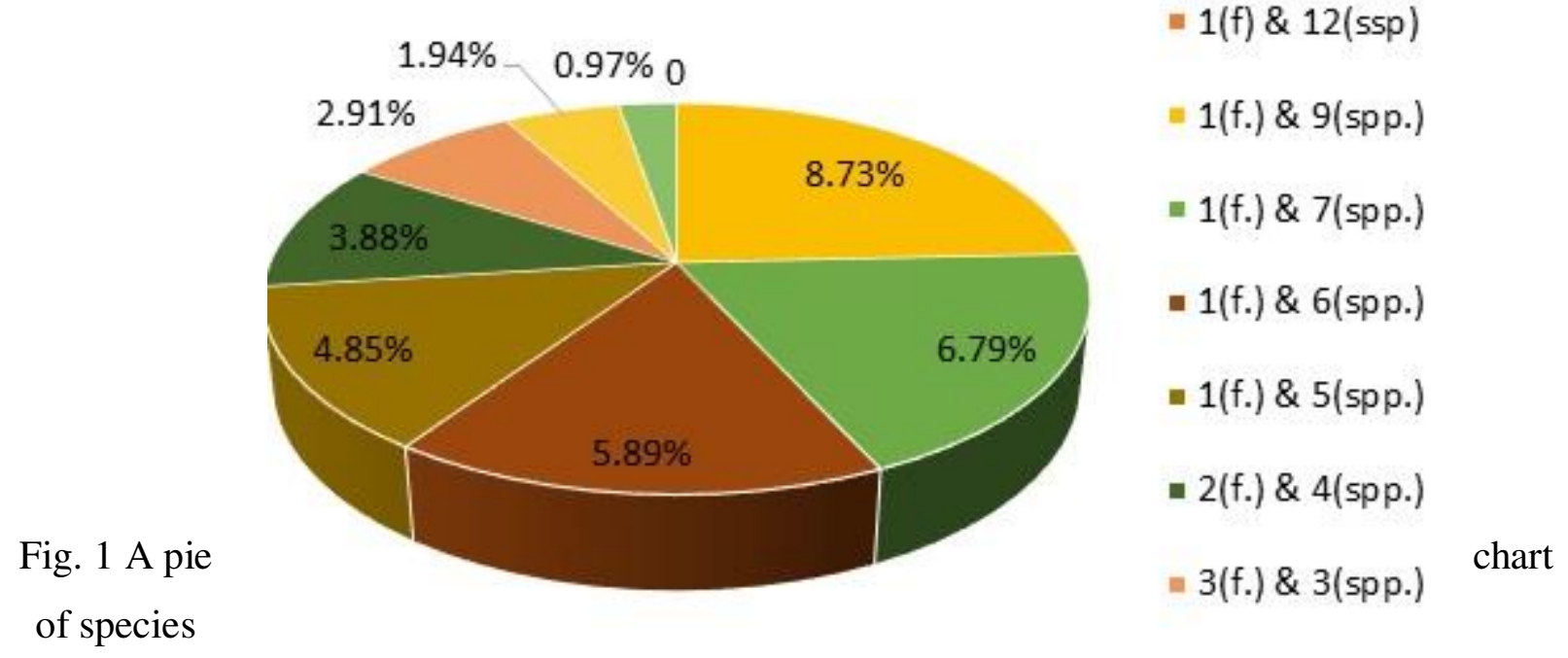

contribution in each family from study area, Azad Jammu and Kashmir

In the investigated area total 103 plant species belonging to 37 families were recorded. Asteraceae was the dominant family of study area with 12 plant species. Somewhat similar ethnomedicinal study was conducted by many researchers on 59 plant species belonging to 35 families being used by local people District Athmaqam, Neelum valley, Azad Jammu and Kashmir [13]. In which Asteraceae was the dominant family of the study area with 8 plant species. These previous findings were strongly correlated and supported our study.

The present study provides information about different uses of 103 plant species belonging to 46 families. We found that 78 species (75\%) had single use, 21 species (20\%) had dual uses and 4 species $(3 \%)$ had multi uses. Single usage plants have been categorized into medicinal, fodder, food and fuel. Among 78 single usage plant species 45 species (58\%) had medicinal uses, 15 species had food and fodder values each and 3 species (3\%) had fuel values. Double usage plant species had been classified into six different categories. Among 21 species, (33\%) had medicinal and food, fodder and food uses. While (14\%) had medicinal plus fodder values, (9\%) had fodder and fuel uses, (4\%) had medicinal plus fuel and medicinal plus condiments values. Multi usage plants have classified into three categories. Among 4 plant species (50\%) were used as medicinal, furniture, fuel and house thatching, (25\%) were used as fodder, ropes, fuel and medicinal, food and fodder. Similar study was conducted on the plants of District Kotli, Azad Jammu and Kashmir, Pakistan [6]. They investigated 93 plants species belonging to 46 families in which $49(52.68 \%)$ plants for single usage, $35(37.63 \%)$ for double purposes and 7 (7.52) for three purposes and 2 
(2.15\%) for multi purposes. Some other researchers were also explored ethnobotanical importance and use of medicinal plants from Khyber Pakhtoonkwa provine of Pakitan [31]. 
Table 4 Traditional ethnobotanical uses of wild plant species recorded from Dawarian to Ratti Gali, District Atmakam, Azad Jammu and Kashmir

\begin{tabular}{|c|c|c|c|c|c|}
\hline $\begin{array}{l}\text { S. } \\
\text { No. }\end{array}$ & Species name & Family & $\begin{array}{l}\text { Collecting } \\
\text { Period }\end{array}$ & Part used & Traditional uses \\
\hline 1 & Acer cappadocicum Gled. & Sapindaceae & Summer & $\begin{array}{l}\text { Leaves, } \\
\text { Wood }\end{array}$ & Leaves are used as fodder. Wood is used as fuel for domestic. \\
\hline \multirow[t]{2}{*}{2} & Ajuga bracteosa Wall. & Lamiaceae & Summer & $\begin{array}{l}\text { Whole } \\
\text { plant }\end{array}$ & $\begin{array}{l}\text { Root extracts are used for purification of blood. Paste of leaves } \\
\text { helpful to cure headache while powder of whole plant is given to } \\
\text { treat abdominal pain. }\end{array}$ \\
\hline & Ajuga parviflora Benth. & Lamiaceae & Summer & $\begin{array}{l}\text { Whole } \\
\text { plant }\end{array}$ & It is used as fermifuged. It is used as fodder. \\
\hline 3 & Allium griffithianum Boiss. & Amaryllidaceae & Summer & Leaves & It is used to cure fever and cough. It is used as food. \\
\hline 4 & Aconogonon alpinum (All.) Schur & Polygonaceae & Summer & $\begin{array}{l}\text { Whole } \\
\text { plant }\end{array}$ & $\begin{array}{l}\text { Leaves are used as food. Root is used for the treatment of joints } \\
\text { pain. }\end{array}$ \\
\hline 5 & Actaea spicata $\mathrm{L}$. & Ranunculaceae & Summer & Roots & Juice of roots is used to kill lice. \\
\hline 6 & $\begin{array}{l}\text { Aesculus indica (Wall. ex Cambess.) } \\
\text { Hook. }\end{array}$ & Spindaceae & Summer & $\begin{array}{l}\text { Whole } \\
\text { plant }\end{array}$ & Leaves are used as fodder. Wood and stem is used as fuel. \\
\hline 7 & $\begin{array}{l}\text { Aconitum heterophyllum Wall. ex } \\
\text { Royle }\end{array}$ & Ranunculaceae & Summer & Root & $\begin{array}{l}\text { Roots are used for the treatment of fever, vomiting, dysentery, } \\
\text { flu cough and abdominal pain with boiled milk. }\end{array}$ \\
\hline 8 & Abies pindrow Royle. & Pinaceae & Summer & Leaves & $\begin{array}{l}\text { The paste of the leaves apply on cuts wounds bruises to get rid } \\
\text { of beacteria and germs. }\end{array}$ \\
\hline 9 & Achillea millefolium $\mathrm{L}$. & Asteraceae & Summer & $\begin{array}{l}\text { Whole } \\
\text { plant }\end{array}$ & $\begin{array}{l}\text { Paste prepared from this plant is used in stanching the flow of } \\
\text { blood from wounds. Leaves are chewed to treat teeth pain. } \\
\text { Leaves juice is poured in ear to treat ear pain. plant is also used } \\
\text { to treat T.B., stomach disorder and fever in form of Tea. }\end{array}$ \\
\hline 10 & Artemisia japonica Thunb. & Asteraceae & Summer & Leaves & The juice of leaves is used for cough and asthma. \\
\hline 11 & Anaphalis triplinervis Clarke & Asteraceae & Summer & $\begin{array}{l}\text { Whole } \\
\text { plant }\end{array}$ & The paste of whole plant is used as tonic for animals. \\
\hline 12 & $\begin{array}{l}\text { Artemisia macrophylla Fisch. ex } \\
\text { Besser }\end{array}$ & Asteraceae & Summer & $\begin{array}{l}\text { Leaves, } \\
\text { Shoot }\end{array}$ & Leaves are used for cough and asthma. Shoot is used for fodder. \\
\hline 13 & Astragalus graveolens Benth. & Papilionaceae & Summer & Fruit & Fruit is eatable. \\
\hline 14 & Ajuga parviflora Benth & Lamiaceae & Summer & $\begin{array}{l}\text { Whole } \\
\text { plant }\end{array}$ & It is used as fodder. \\
\hline
\end{tabular}




\begin{tabular}{|c|c|c|c|c|c|}
\hline 15 & Adiantum aethiopicum $\mathrm{L}$. & Pteridaceae & Summer & Leaves & $\begin{array}{l}\text { Juice of leaves is used for the treatment of chest burning, } \\
\text { stomachache and blood purification. }\end{array}$ \\
\hline 16 & Arisaema tortuosum (Wall.) Schott & Araceae & Summer & $\begin{array}{l}\text { Whole } \\
\text { plant }\end{array}$ & $\begin{array}{l}\text { The roots are used as wormicide. The extrat of leaf is used to cure } \\
\text { cattle worms and stomach issues.the dried tubers are used as cure } \\
\text { of snake poison. }\end{array}$ \\
\hline 17 & Astragalus chlorostachys Bunge & Papilionaceae & Summer & $\begin{array}{l}\text { Whole } \\
\text { plant }\end{array}$ & The plant is used as fodder for the livestock and cattle. \\
\hline 18 & Bergenia ciliata (Haw.) Sternb. & Saxifragaceae & Summer & $\begin{array}{l}\text { Whole } \\
\text { plant }\end{array}$ & $\begin{array}{l}\text { Extracts of leaves is used as earaches relieve while roots are } \\
\text { used as a tonic in treatment of fevers, diarrhoea and pulmonary } \\
\text { affections. }\end{array}$ \\
\hline 19 & Bromus pectinatus Thunb. & Poaceae & Summer & $\begin{array}{l}\text { Whole } \\
\text { plant }\end{array}$ & It is used as fodder. \\
\hline 20 & Berberis lycium Royle & Berberidaceae & Summer & Leaves & $\begin{array}{l}\text { Dried leaves are used for the treatment of headache, } \\
\text { stomachache, joints pain and teethache. Boiled water of roots is } \\
\text { used to treat internal wounds, especially bone fracture. }\end{array}$ \\
\hline 21 & $\begin{array}{l}\text { Bistorta amplexicaulis (D.Don) } \\
\text { Greene }\end{array}$ & Polygonaceae & Summer & $\begin{array}{l}\text { Root, } \\
\text { Leaves }\end{array}$ & $\begin{array}{l}\text { Dried roots are used in making tea. The herbaceous roots are } \\
\text { also used as fodder or cattle. }\end{array}$ \\
\hline 22 & Buddleja crispa Benth. & Buddlejaceae & Summer & $\begin{array}{l}\text { Whole } \\
\text { plant }\end{array}$ & It is used as fodder. \\
\hline 23 & Buxus wallichiana Baill. & Buxaceae & Summer & Leaves & $\begin{array}{l}\text { Dried leaves are used in the treatment of joints pain and muscles } \\
\text { pain. }\end{array}$ \\
\hline 24 & Convolvulus arvensis L. & Convolvulaceae & Summer & Leaves & Leaves are used as vegetable. It is also used as fodder. \\
\hline 25 & Cirsium arvense (L.) Scop. & Astraceae & Summer & $\begin{array}{l}\text { Whole } \\
\text { plant }\end{array}$ & Powdered form mix with water is used as tonic. \\
\hline 26 & Campanula pallida Wall. & Campanulaceae & Summer & $\begin{array}{l}\text { Whole } \\
\text { plant }\end{array}$ & It is used as fodder. \\
\hline 27 & Cynoglossum lanceolatum Forssk. & Boraginaceae & Summer & $\begin{array}{l}\text { Whole } \\
\text { plant }\end{array}$ & $\begin{array}{l}\text { The foliar past is applied on abscess to remove pus. It is also use } \\
\text { in asthma. }\end{array}$ \\
\hline 28 & Cuscuta reflexa Roxb. & Convolvulaceae & Summer & $\begin{array}{l}\text { Whole } \\
\text { plant }\end{array}$ & $\begin{array}{l}\text { Juice of the whole plant used to increase the length of hairs and } \\
\text { make strong. It is also used as fodder. }\end{array}$ \\
\hline 29 & $\begin{array}{l}\text { Cedrus deodara (Roxb. ex D.Don) } \\
\text { G.Don }\end{array}$ & Pinaceae & Summer & Wood & $\begin{array}{l}\text { Oil of wood is used for toothache, applied to skin for skin } \\
\text { problems. Wood is also used as fuel. }\end{array}$ \\
\hline 30 & Colchicum luteum Baker & Colchicaceae & Summer & $\begin{array}{l}\text { Whole } \\
\text { plant }\end{array}$ & Juice of plant is used for purification of blood. \\
\hline 31 & Corylus colurna L. & Butalaceae & Summer & Fruit & Fruit is eatable. \\
\hline 32 & Corydalis vaginans Royle & Fumariaceae & Summer & Sap & The sap of the plant is used in the treatment of eye diseases. \\
\hline
\end{tabular}




\begin{tabular}{|c|c|c|c|c|c|}
\hline 33 & $\begin{array}{l}\text { Cotoneaster microphyllus Wall. ex } \\
\text { Lindl. }\end{array}$ & Rosaceae & Summer & $\begin{array}{l}\text { Whole } \\
\text { plant }\end{array}$ & It is used as fodder for cattle and goats. \\
\hline 34 & Corydalis govaniana Wall. & Fumariaceae & Summer & Leaves & $\begin{array}{l}\text { Juice of leaves is used for the treatment of fever and skin } \\
\text { problem. }\end{array}$ \\
\hline 35 & Caltha alba Cambess. & Ranunculaceae & Summer & $\begin{array}{l}\text { Whole } \\
\text { plant }\end{array}$ & $\begin{array}{l}\text { Dried powdered or juice of this plant is used to reduce muscle } \\
\text { pain and sedative. }\end{array}$ \\
\hline 36 & Cenchrus pennisetiformis Steud. & Poaceae & Summer & $\begin{array}{l}\text { Whole } \\
\text { plant }\end{array}$ & It is used as fodder for cattle and rodents. \\
\hline 37 & Clinopodium vulgare $\mathrm{L}$. & Lamiaceae & Summer & Leaves & A sweet and aromatic herb tea is made from the fresh leaves. \\
\hline 38 & Digitaria cruciata (Nees) A.Camus & Poaceae & Summer & $\begin{array}{l}\text { Whloe } \\
\text { plant }\end{array}$ & It is used as fodder for cattle and goats. \\
\hline 39 & Erysimum hieraciifolium L. f. & Brassicaceae & Summer & $\begin{array}{l}\text { Whole } \\
\text { plant }\end{array}$ & It is used as food and source of vegetable. \\
\hline 40 & Erysimum hedgeanum Al-Shehbaz & Brassicaceae & Summer & $\begin{array}{l}\text { Whole } \\
\text { plant }\end{array}$ & $\begin{array}{l}\text { This is poisoneous herb. The juice of whole plant is use to kill } \\
\text { lices in animals. }\end{array}$ \\
\hline 41 & Euonymus hemsleyanus Loes. & Calastraceae & Summer & $\begin{array}{l}\text { Whole } \\
\text { plant }\end{array}$ & It is used as fodder cattle and rodents. \\
\hline 42 & Elsholtzia strobilifera (Benth.) Benth. & Lamiaceae & Summer & $\begin{array}{l}\text { Whole } \\
\text { plant }\end{array}$ & It is used as fodder cattle and rodents. \\
\hline 43 & Fragaria nubicola Lacaita & Rosaceae & Summer & Fruit & Fruit is eatable and used as antioxidant agent. \\
\hline 44 & Geranium rotundifolium $\mathrm{L}$. & Geraniaceae & Summer & $\begin{array}{l}\text { Root, } \\
\text { Leaves }\end{array}$ & $\begin{array}{l}\text { Dried root powder is doted on wounds. The dried roots were } \\
\text { grinded, sugar and milk are added in it, and then used for pain } \\
\text { relief of joints. }\end{array}$ \\
\hline 45 & Geranium villosum Ten. & Geraniaceae & Summer & $\begin{array}{l}\text { Whole } \\
\text { plant }\end{array}$ & It is used as food for cure of edema. \\
\hline 46 & Gerbera gossypina (Royle) Beauverd & Asteraceae & Summer & $\begin{array}{l}\text { Whole } \\
\text { plant }\end{array}$ & It is used as fodder cattle and rodents. \\
\hline 47 & $\begin{array}{l}\text { Hylotelephium ewersii (Ledeb.) } \\
\text { H.Ohba }\end{array}$ & Crassulaceae & Summer & Leaves & $\begin{array}{l}\text { It is believed to be having cooling effect if the juice of the leaves } \\
\text { mix with water and drink. }\end{array}$ \\
\hline 48 & Ilex dipyrena Wall. & Aquifoliaceae & Summer & Leaves & It is used as fodder. It is also the source of fuel and wood. \\
\hline 49 & Indigofera heterantha Brandis & Papilionaceae & Summer & Shoots & Shoots are used as fodder, branches as ropes, brooms and fuel. \\
\hline 50 & Isodon rugosus (Wall.) Codd & Lamiaceae & Summer & Leaves & Juice of the leaves is used for stomachache. \\
\hline
\end{tabular}




\begin{tabular}{|c|c|c|c|c|c|}
\hline 51 & Juncus arcuatus Wahlenb. & Juncaceae & Summer & $\begin{array}{l}\text { Whole } \\
\text { plant }\end{array}$ & It is used as fodder cattle and rodents. \\
\hline 52 & Juniperus communis Brand. & Cupressaceae & summer & Wood & It is the source of fuel and commercial wood. \\
\hline 53 & Lespedeza juncea (L.f.) Pers. & Papilionaceae & Summer & Leaves & It is used as fodder cattle and rodents. \\
\hline 54 & Ligularia thomsonii Clarke. & Asteraceae & Summer & Root & $\begin{array}{l}\text { Dried root or powdered of root is used in the treatment of } \\
\text { asthma, stimulate blood flow, reduce inflammation and stopping } \\
\text { cough. }\end{array}$ \\
\hline 55 & Mentha longifolia L. & Lamiaceae & Summer & $\begin{array}{l}\text { Whole } \\
\text { plant }\end{array}$ & $\begin{array}{l}\text { Shoot is used for stomachache and gas trouble. Juice of leaves } \\
\text { expels worms from the stomach. It is also as condiment. }\end{array}$ \\
\hline 56 & Matricaria chamomilla $\mathrm{L}$. & Asteraceae & Summer & Root & Root is used for toothache. \\
\hline 57 & Morina persica $\mathrm{L}$. & Caprifoliaceae & Summer & Aerial parts & It is used for treatment of cold. \\
\hline 58 & Meliosma simplicifolia (Roxb.) Walp. & Sabiaceae & Summer & $\begin{array}{l}\text { Leaves, } \\
\text { Wood }\end{array}$ & Leaves asre used as fodder. It is also source of fuel. \\
\hline 59 & Oxalis corniculata $\mathrm{L}$. & Oxalidaceae & Summer & $\begin{array}{l}\text { Leaves, } \\
\text { Flowers }\end{array}$ & $\begin{array}{l}\text { Juice of leaves and flowers mixed together is used for the } \\
\text { treatment of eyes. }\end{array}$ \\
\hline 60 & Onychium japonicum (Thunb.) Kunze & Pteridaceae & Summer & $\begin{array}{l}\text { Whole } \\
\text { palnt }\end{array}$ & $\begin{array}{l}\text { It is used as vegetable. Dried root or powdered root is used for } \\
\text { the treatment of asthma and flu. }\end{array}$ \\
\hline 61 & Oxyria digyna (L.) Hill & Polygonaceae & Summer & Shoot & $\begin{array}{l}\text { Shoot extracts are used for constipation, liver disorders and } \\
\text { stomachache. }\end{array}$ \\
\hline 62 & Onosma bracteata Wall. & Boraginaceae & Summer & $\begin{array}{l}\text { Whole } \\
\text { plant }\end{array}$ & $\begin{array}{l}\text { Powder of dry root is used against asthma and bronchitis. } \\
\text { Decoction of leaves is given in stomach and bladder irritation. }\end{array}$ \\
\hline 63 & Origanum vulgare L. & Lamiaceae & Summer & $\begin{array}{l}\text { Whole } \\
\text { plant }\end{array}$ & $\begin{array}{l}\text { It is used for muscles pain, cold and tootache. It is also as } \\
\text { vegetable and fodder. }\end{array}$ \\
\hline 64 & Polygala chinensis L. & Polygalaceae & Summer & $\begin{array}{l}\text { Whole } \\
\text { plant }\end{array}$ & This plant is used for treatment of snake bites. \\
\hline 65 & Phlomis bracteosa Royle ex Benth. & Lamiaceae & Summer & $\begin{array}{l}\text { Leaves, } \\
\text { Flowers }\end{array}$ & $\begin{array}{l}\text { Powdered leaves are mixed in tea and used against cough and } \\
\text { cold. Flowers are crushed and used against tootache. }\end{array}$ \\
\hline 66 & Pedicularis brevifolia D.Don & Orobanchaceae & Summer & $\begin{array}{l}\text { Leaver, } \\
\text { Root }\end{array}$ & $\begin{array}{l}\text { Powdered leaves is used for the treatment of cough, fever, } \\
\text { asthma and skin disease. Dried or powdered root is used for the } \\
\text { treatment of stomachache. }\end{array}$ \\
\hline 67 & Primula denticulata $\mathrm{Sm}$. & Primalaceae & Summer & Stem & Juice of stem is used for eye diseases. \\
\hline
\end{tabular}




\begin{tabular}{|c|c|c|c|c|c|}
\hline 68 & Podophyllum hexandrum Royle & Barberidaceae & Summer & Leaves & $\begin{array}{l}\text { Powdered leaves is used in the treatment of asthma. It is also } \\
\text { used to reduce bulb in throat. }\end{array}$ \\
\hline 69 & Populus alba L. & Salicaceae & Summer & $\begin{array}{l}\text { Whole } \\
\text { plant }\end{array}$ & Leaves are used as fodder. Wood is used as fuel. \\
\hline 70 & Plantago lanceolata $\mathrm{L}$. & Plantaginaceae & Summer & $\begin{array}{l}\text { Whole } \\
\text { plant }\end{array}$ & It is used as vegetable and laxatice. \\
\hline 71 & Persicaria mitis (Schrank) Holub & Polygonaceae & Summer & Root & Tea is made by root which help to reduce the joints pain. \\
\hline 72 & Picea smithiana (Wall.) Boiss. & Pinaceae & Summer & Wood & Wood is the source of fuel. \\
\hline 73 & $\begin{array}{l}\text { Podophyllum emodi Wall. ex Hook.f. } \\
\& \text { Thomson }\end{array}$ & Barberidaceae & Summer & Whole & It is used as fodder cattle and rodents. \\
\hline 74 & Pinus wallichiana A.B.Jacks. & Pinaceae & Summer & $\begin{array}{l}\text { Whole } \\
\text { plant }\end{array}$ & $\begin{array}{l}\text { Smell of resin reduce severe cough. Powder of leaves and bark } \\
\text { used with cold water useful for dysentery. Wood is used to make } \\
\text { house thatching. Cones are used for fuel purposes and seeds are } \\
\text { edible. }\end{array}$ \\
\hline 75 & Pinus roxburghii Sarg. & Pinaceae & Summer & $\begin{array}{l}\text { Whole } \\
\text { plant }\end{array}$ & $\begin{array}{l}\text { Powder of leaves and bark used with cold water for dysentery. } \\
\text { Wood is used for furniture and fire purpose. Smoke is used to } \\
\text { repel the mosquitoes and other insects. }\end{array}$ \\
\hline 76 & Rosa macrophylla Lindl. & Rosaceae & Summer & Fruit & Fruit is used in fever to cure from it. \\
\hline 77 & Rheum emodi Wall. & Polygonaceae & Summer & $\begin{array}{l}\text { Whole } \\
\text { plant }\end{array}$ & $\begin{array}{l}\text { Leaves are used as vegetable. The powdered root and stem mix } \\
\text { together with hot water to relieve constipation. }\end{array}$ \\
\hline 78 & $\begin{array}{l}\text { Rubus niveus subsp. horsfieldii (Miq.) } \\
\text { Focke }\end{array}$ & Rosaceae & Summer & Fruit & Fruit is eatable. \\
\hline 79 & Rheum australe D. Don & Polygonaceae & Summer & $\begin{array}{l}\text { Root, } \\
\text { Leaves }\end{array}$ & $\begin{array}{l}\text { Leaves are used as vegetable. Paste of root is used for wound } \\
\text { healing. }\end{array}$ \\
\hline 80 & Rhus succedanea L. & Anacardiaceae & Summer & $\begin{array}{l}\text { Whole } \\
\text { plant }\end{array}$ & It is used as fodder. It is also source of fuel. \\
\hline 81 & Saussurea lappa (Decne.) Sch.Bip. & Asteraceae & Summer & Root & $\begin{array}{l}\text { Powder of root is used for cough and tootache, also as } \\
\text { vermifusefor intestinal worm. Juice of root is used with a } \\
\text { sweetner to cure rheumatism and pneumonia. }\end{array}$ \\
\hline 82 & Silene vulgaris Garcke. & Caryophyllaceae & Summer & $\begin{array}{l}\text { Whole } \\
\text { plant }\end{array}$ & It is used as vegetable. \\
\hline
\end{tabular}




\begin{tabular}{|c|c|c|c|c|c|}
\hline 83 & Sonchus asper Hill. & Asteraceae & Summer & $\begin{array}{l}\text { Whole } \\
\text { plant }\end{array}$ & Young leaves and stem is cooked as vegetable. \\
\hline 84 & Sorghum halepense Pers. & Poaceae & Summer & $\begin{array}{l}\text { Whole } \\
\text { plant }\end{array}$ & Juice of root is used for the asthma. It is also used for fodder. \\
\hline 85 & Senecio chrysanthemoides DC. & Asteraceae & Summer & $\begin{array}{l}\text { Whole } \\
\text { plant }\end{array}$ & It is used as vegetable. \\
\hline 86 & Skimmia laureola Franch. & Rutaceae & Summer & Leaves & $\begin{array}{l}\text { Tea is made by dry leaves which is very effective in joints pain, } \\
\text { muscles pain, stomach pain and bone pain. Powdered leaves also } \\
\text { used in deserts. }\end{array}$ \\
\hline 87 & Salix tetrasperma Roxb. & Salicaceae & Summer & $\begin{array}{l}\text { Whole } \\
\text { plant }\end{array}$ & It is used as fodder. Wood is used as fuel. \\
\hline 88 & Symplocos paniculata (Thunb.) Miq. & Symplocaceae & Summer & Leaves & $\begin{array}{l}\text { Powdered leaves is used in the treatment of menorrhagia, eye } \\
\text { disease. }\end{array}$ \\
\hline 89 & Sarcococca saligna Müll.Arg. & Buxaceae & Summer & Leaves & $\begin{array}{l}\text { Powdered leaves is used in constipation, blood purification and } \\
\text { muscles relaxation. }\end{array}$ \\
\hline 90 & Satyrium nepalense D.Don & Orchidaceae & Summer & Tuber & Tubers are used as tonic and to cure dysentery and malaria fever. \\
\hline 91 & Scutellaria linearis Benth. & Lamiaceae & Summer & Leaves & Powdered leavesis used to reduce inflammation and diarrhea. \\
\hline 92 & Swertia paniculata Wall. & Gentianaceae & Summer & $\begin{array}{l}\text { Whole } \\
\text { plant }\end{array}$ & Powdered plant is used to cure from fever. \\
\hline 93 & Solidago capitata Fisch. ex Herder & Asteraceae & Summer & $\begin{array}{l}\text { Whole } \\
\text { plant }\end{array}$ & Powdered plant is used to heal wounds. \\
\hline 94 & Thymus linearis Benth. & Lamiaceae & Summer & $\begin{array}{l}\text { Whole } \\
\text { plant }\end{array}$ & $\begin{array}{l}\text { Tea is made by this plant which help to reduce fats in body, } \\
\text { abdominal pain and gas trouble. }\end{array}$ \\
\hline 95 & Taxus baccata $\mathrm{L}$. & Taxaceae & Summer & wood & It is used as fuel. \\
\hline
\end{tabular}




\begin{tabular}{|c|c|c|c|c|c|}
\hline 96 & Trifolium repens $\mathrm{L}$. & Papilionaceae & Summer & Leaves & Used as vegetables. \\
\hline 97 & Viola biflora $\mathrm{L}$. & Violaceae & Summer & Leaves & $\begin{array}{l}\text { Leaves are used as vegetables. Tea is made by dry leaves which } \\
\text { helps in cough headache and flu. }\end{array}$ \\
\hline 98 & Vicia sativa $\mathrm{L}$. & Papilionaceae & Summer & Leaves & Leaves are used as vegetable. \\
\hline 99 & Viburnum cotinifolium Don. & Caprifoliaceae & Summer & Fruit & Fruit is eatable. \\
\hline 100 & Viscum album $\mathrm{L}$. & Viscaceae & Summer & Leaves & Powdered leaves are used in the treatment of cough and asthma. \\
\hline 101 & Valeriana jatamansi Jones & Caprifoliaceae & Summer & Root & $\begin{array}{l}\text { Powdered root is used for the treatment of joints pain. It is also } \\
\text { used in sweet dishes. }\end{array}$ \\
\hline 102 & Viola canescens Wall. & Violaceae & Summer & $\begin{array}{l}\text { Leaves, } \\
\text { Flowers }\end{array}$ & $\begin{array}{l}\text { Powder of leaves and flowers is given internally in the treatment } \\
\text { of coughs and asthma. }\end{array}$ \\
\hline 103 & Wulfenia amherstiana Benth. & Plantaginaceae & Summer & $\begin{array}{l}\text { Whole } \\
\text { plant }\end{array}$ & It is used as fodder cattle and rodents. \\
\hline
\end{tabular}




\section{Summary of ethnobotanical investigation}

To summarize the identified (103 plants) species in pie-chart as; out of which $75.72 \%$ were single usage, $20.38 \%$ were dual usages and $3.88 \%$ were multiple usages. A pie-chart of all plants uses is given in Fig. 2.

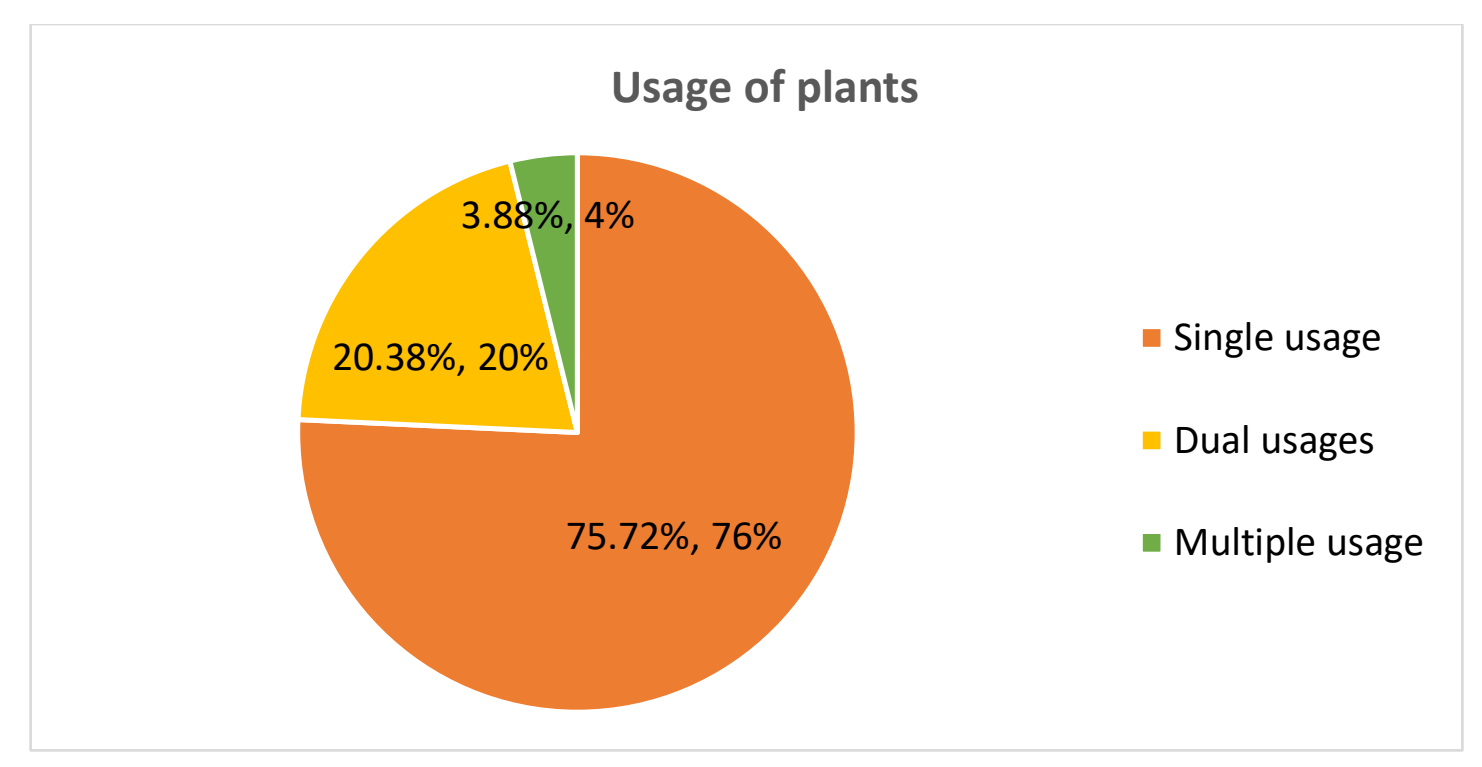

Fig. 2 Graphical presentation of plants on the basis of their usage

\section{Single-usage plants}

The plants which are used for only one purpose are called single-usage plant, e.g. Solidago capitata used as a medicinal purpose. Out of 103 plant species reported from the study area (Dowariya and Rati Gali), 78 were single usage. Out of 78 plants, medicinal plants were 45 (57.69\%), whereas food, fodder and fuel were 15 (19.23\%), 15 (19.23\%) and 3 (3.84\%) respectively. A pie-chart of all single-usage plants is given in Fig. 3. These findings were strongly correlated with Uniyal medicinal practices in Kangra district of Himachal Pradesh, Western Himalaya [32]. 


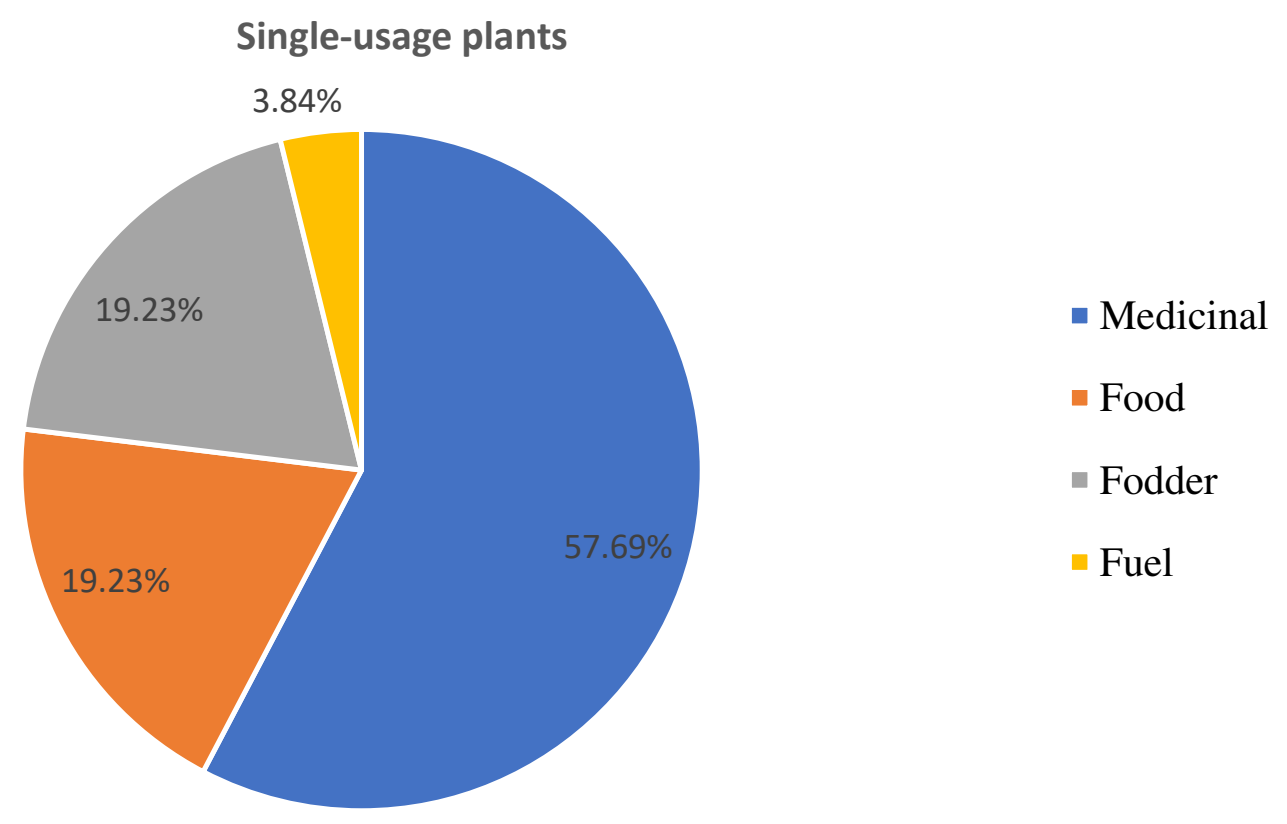

Fig. 3 A pie-chart of single-usage plants

\section{Dual-usage plants}

The plants that used for two key purposes, are called dual-usage plants. For example, Artemisia macrophylla is used for medicinal as well as fodder. Out of 103 plants species, 21 (20.38\%) were representing dual-usage plants. There were 6 categories of dual-usage of plants representing 21 species, i.e. medicinal \& food and fodder \& fuel were 7 (33.33\%) while medicinal $\&$ fodder and food \& fodder were $3(14.28 \%)$ and $2(9.52 \%)$ respectively. Medicinal \& condiments and medicinal \& fuel were 1 (4.76\%). A pie-chart of all dual-usage plants is given in (Fig. 4). Many researchers positively correlate with our findings as Polat and his co-researchers discussed an ethnobotanical use of medicinal plants in Espiye and its surroundings in 2015 [33]. 


\section{Dual-usage plants \%}

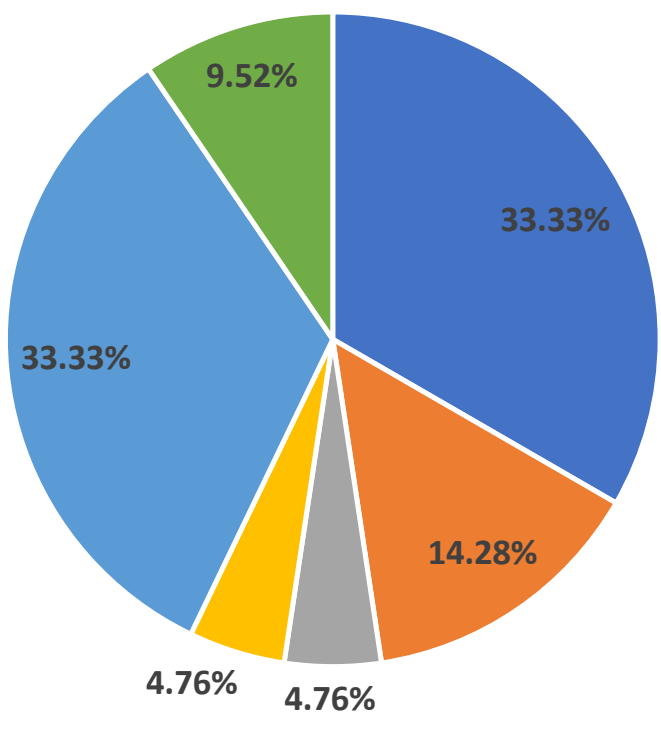

- Medicinal \& food

- Medicinal \&fodder

- Medicinal \& condiments

- Medicinal \& fuel

- Fodder \& fuel

- Fodder \& food

Fig. 4 A pie-chart of dual usage plants

Dosage form such as powdered, juice, mixture and decoction were frequently used for the treatment of different diseases in the study area. Powdered is the dosage form having the highest percentage $38 \%$ used among the local people, after that juice is widely used by the local people having the percentage of about $29 \%$ while the least administrated form is oil $1.61 \%$. Other purposes such as fodder, food, fuel and construction were used by local people. Mostly plants frequently used for domestic animals as fodder having the highest percentage $37 \%$, and after that as food is widely used by the local people having percentage of about $32 \%$. Similar studies were conducted on the plants of Kel village, Neelum Valley, Azad Jammu and Kashmir. They investigated 50 plants belonging to 33 families from the study area [24]. Among plant part utilized, Leaves $(30 \%)$ and the entire plant $(23 \%)$ were the most much of the time utilized plant parts followed by roots $(14 \%)$, bark $(11 \%)$, seeds $(8 \%)$, natural products $(6 \%)$ elevated parts and stem (3\%) and blossoms (2\%) while the most widely recognized strategies for readiness was decoction $(20 \%)$, extricate $(17 \%)$, mixture $(15 \%)$, powder and squeeze (13\% each), glue (11\%), poultice (7\%), and oil (8\%). Comparative tradicional employments of therapeutic plants were additionally investigated by Oliver in 2013 [34].

\section{Multiple-usage plants}


The plants which are used for multiple purposes, are called multiple-usage, e.g. Pinus wallichiana A.B.Jacks. is used for fuel, furniture, medicinal and thatching. Out of 103 plant species, 4 were representing multi-usage plants. There were 3 categories of multi-usage plants representing 4 plant species. Out of 4 plants, fodder, ropes and fuel were 1(25\%), medicinal, furniture, fuel and thatching were 2(50\%) while Medicinal, food and fodder were 1(25\%). A list of all the multiple-usage plants, their local names and families is given in (Table 6). While a piechart of all multiple-usage plants is given in (Fig.5). Similar multiple Traditional use of medicinal plants among Kalasha, Ismaeli and Sunni groups in Chitral District, Khyber Pakhtunkhwa province Pakistan were documented in year 2016 [31].

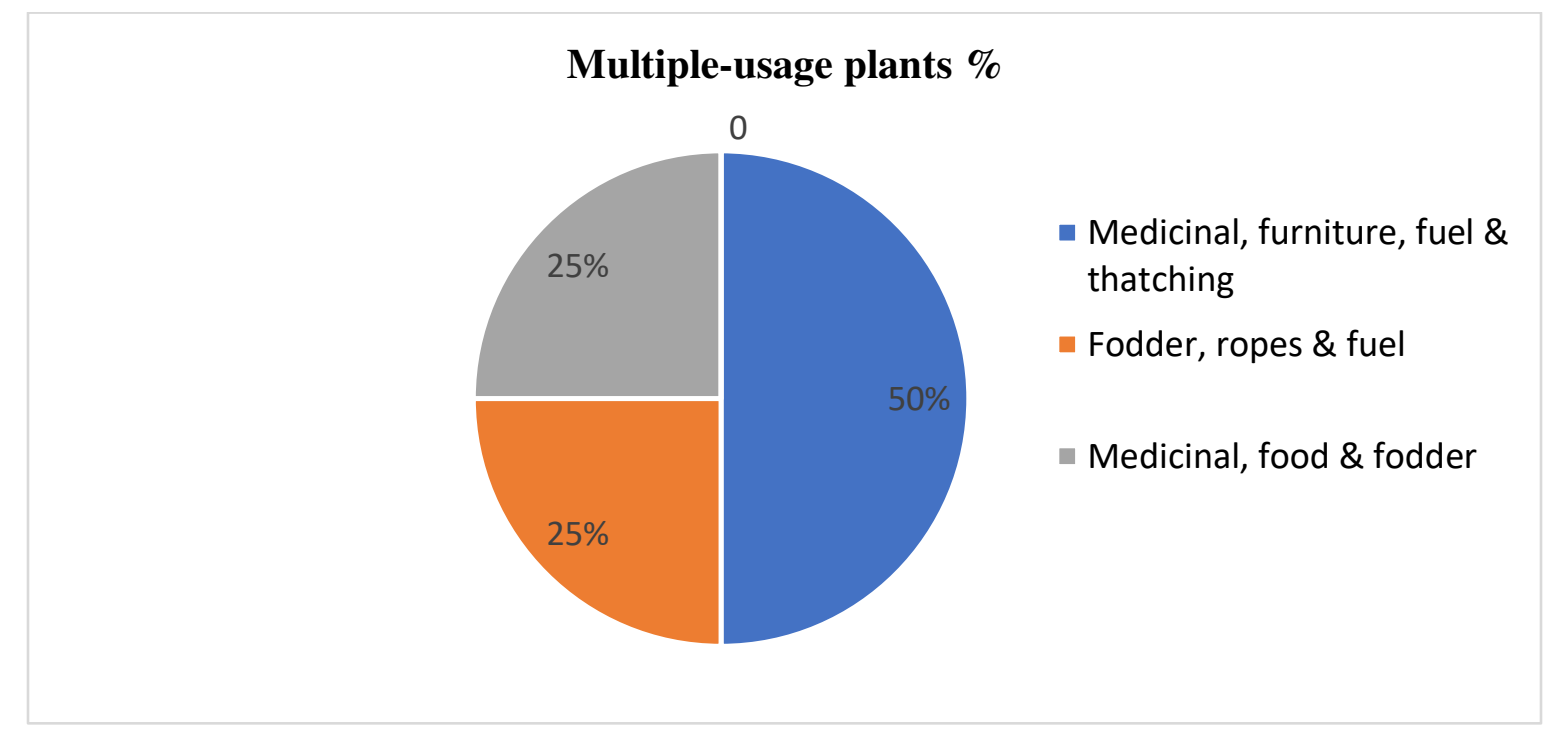

Fig. 5 A pie chart of multiple-usage plants

Similar research was conducted on the plants of Darguti, Tehsil Khuiratta, AJK, Pakistan were being used by the local population of the area [16]. The plants species have single, double and multiple usages. 12 plant species have single uses, 24 have double uses and 64 species have multiple uses which is quite match with our findings. This district falls in subtropic region but my study area occurs in temperate region. Therefore, few plants species were grown different from our research area. 


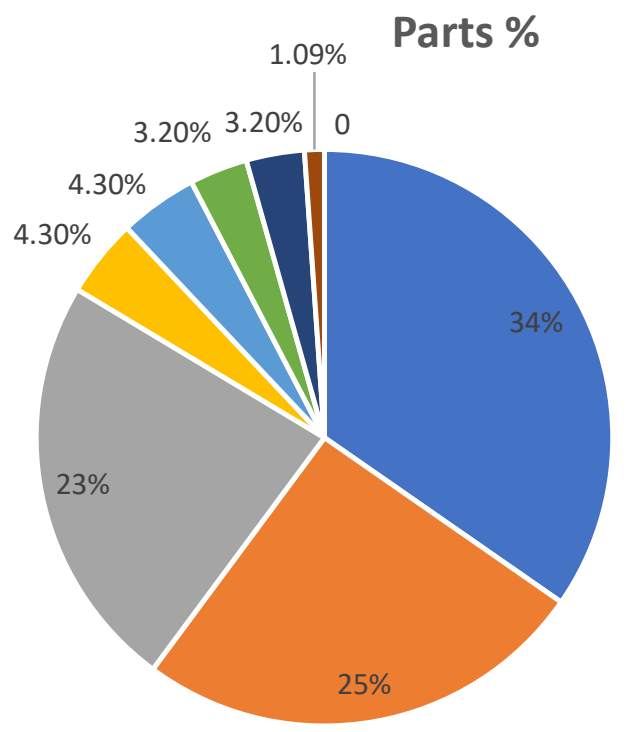

- Leaves

- Roots

- Whole plants

- Stem

- Flower

- Shoot

- Tuber

- Fruit

- Sap

Fig. 6 A pie-chat of different parts of plants used for the treatment of different diseases

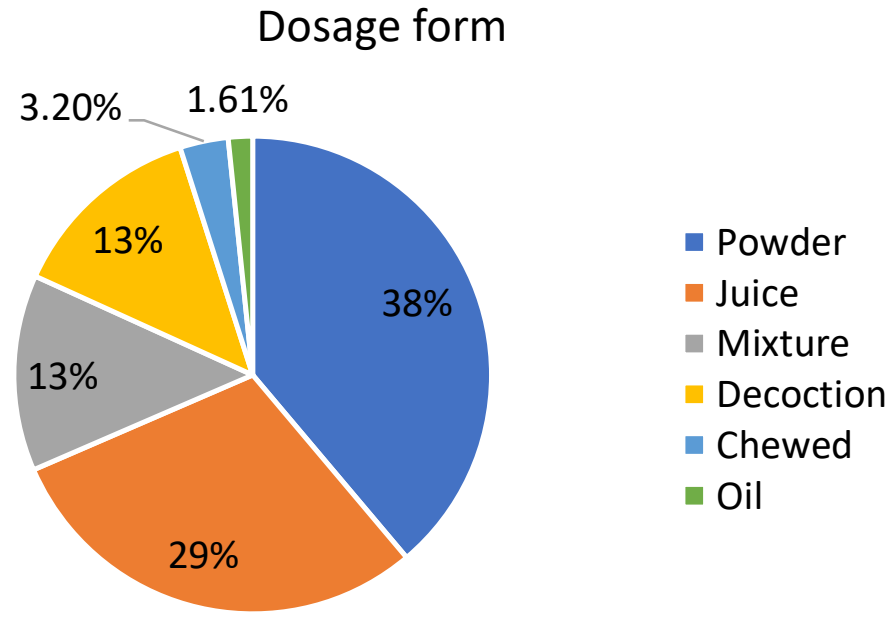

Fig.7 A pie chart of Dosage form used against diseases 


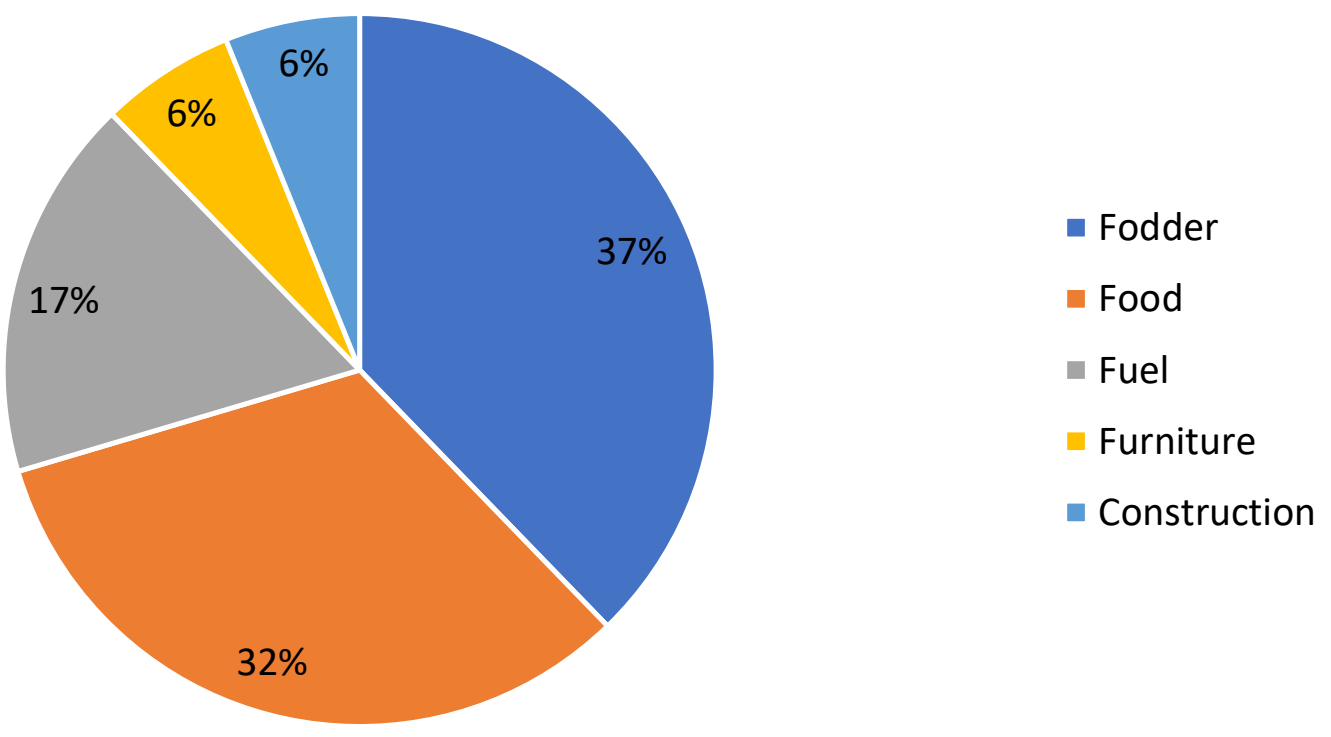

Fig. 8 A Pie chart of different plants used by local people in different categories

Fidelity level of the data depicts that Allium griffithianum (Jungli pyaz) and Fragaria nubicola (Mehwa) is the leading species with $75 \%$ value which is frequently used by local people of Dawarian. Second most important plant with respect to fidelity level of about is the Mentha longifolia (Pahari podina) with $72 \%$. Whole plant is used for stomachache and gas trouble. Juice of the leaves expel worm from the stomach. It is also used as condiments. Third plant with respect to fidelity level is Abies pindrow (Partel), the paste of the leaves applied on cuts wounds bruises to get rid of bacteria and germs (Table 8). It is also the source of fuel. Ahmad and his colleagues conducted similar studies on the plants of Kel village, Neelum Valley, Azad Jammu and Kashmir [24]. They researched that the species having the most elevated FL esteem were Berberis lyceum (95\%) utilized in jaundice, hepatitis, typhoid, fever, and tuberculosis issues, trailed by Dioscorea bulbifera, Impatiens glandulifera (90\%) utilized in stiffness, joint torment and Artemisia vulgaris (90\%) utilized in liver issues. Additionally, FL level was likewise seen by Farooq and his exploration bunch [26]. Five plant species including Berberis lyceum, Mentha arvensis Pyrus malus, Taraxacum officinale, and Viola canescens had 100\% loyalty level.

Table 8 Fidelity level of plants in study area of Dawarian to Ratti Gali, AJK 


\begin{tabular}{|l|l|l|l|l|}
\hline $\begin{array}{l}\text { Sr. } \\
\text { No. }\end{array}$ & Species name & Local name & FL & $\begin{array}{c}\text { F.L\% } \\
\mathbf{N P}\end{array}$ \\
\hline 1 & Acer cappadocicum & Tra kanna & 20 & $50 \%$ \\
\hline 2 & Ajua bracteosa & Jan-e-Adam & 15 & $37 \%$ \\
\hline & Ajuga parviflora & Chita chaou & 24 & $60 \%$ \\
\hline 3 & Allium griffithianum & Jungli pyaz & 30 & $75 \%$ \\
\hline 5 & Aconogonon alpinum & Chikro & 25 & $62 \%$ \\
\hline 6 & Actaea spicata & Moneeri & 20 & $50 \%$ \\
\hline 7 & Acsculus indica & Ban khaur & 10 & $25 \%$ \\
\hline 8 & Abies pindrow & Ptrees & 18 & $45 \%$ \\
\hline 9 & Achillea millefolium & Partal & 28 & $70 \%$ \\
\hline 10 & Artemisia japonica & Gandana & 10 & $25 \%$ \\
\hline 11 & Anaphalis triplinervis & But mehndi & 5 & $12 \%$ \\
\hline 12 & Artemisia macrophylla & Chita chaou & 17 & $42 \%$ \\
\hline 13 & Astragalus graveolens & Ban phali & 21 & $52 \%$ \\
\hline 15 & Adiantum aethiopicum & Kahkawa & 30 & $75 \%$ \\
\hline 16 & Arisaema tortuosum & Sanp ki jari & 9 & $22 \%$ \\
\hline 17 & Astragalus chlorostachys & Phut kanda & 12 & $30 \%$ \\
\hline 18 & Bergenia ciliata & Betbewa & 25 & $62 \%$ \\
\hline 19 & Bromus pectinatus & Pero & 5 & $12 \%$ \\
\hline 20 & Berberis lycium & Sumbal & 19 & $47 \%$ \\
\hline 21 & Bistorta amplexicaulis & Masloon & 18 & $45 \%$ \\
\hline 22 & Buddleja crispa & Gansu & 10 & $25 \%$ \\
\hline 23 & Buxus wallichiana & Chiriri & 17 & $42 \%$ \\
\hline 24 & Convolvulus arvensis & Berrhi & 14 & 35 \\
\hline 25 & Cirsium arvense & Jungli kandyara & 8 & $20 \%$ \\
\hline 26 & Campanula pallida & Bikh & 10 & $25 \%$ \\
\hline 27 & Cynoglossum lanceolatum & Chiro & 12 & $30 \%$ \\
\hline 28 & Cuscuta reflexa & Neela tari & 3 & $7 \%$ \\
\hline
\end{tabular}




\begin{tabular}{|c|c|c|c|c|}
\hline 29 & Cedrus deodara & Devdaar & 16 & $40 \%$ \\
\hline 30 & Colchicum luteum & Sorinjan & 11 & $27 \%$ \\
\hline 31 & Corylus colurna & Aurni & 25 & $62 \%$ \\
\hline 32 & Corydalis vaginans & Mameeri & 9 & $22 \%$ \\
\hline 33 & Cotoneaster microphyllus & Loni & 12 & $30 \%$ \\
\hline 34 & Corydalis govaniana & Bhutkas & 15 & $37 \%$ \\
\hline 35 & Caltha alba & Makanpath & 7 & $17 \%$ \\
\hline 36 & Cenchrus pennisetiformis & Lidder & 6 & $15 \%$ \\
\hline 37 & Clinopodium vulgare & Asaba-el-fetiyal & 23 & $57 \%$ \\
\hline 38 & Digitaria cruciata & Ghaa & 4 & $10 \%$ \\
\hline 39 & Erysimum hieraciifolium & Mirchi & 11 & $27 \%$ \\
\hline 40 & Erysimum hedgeanum & Maneera & 20 & $50 \%$ \\
\hline 41 & Euonymus hemsleyanus & Seeki & 3 & $7 \%$ \\
\hline 42 & Elsholtzia strobilifera & Perilla & 10 & $25 \%$ \\
\hline 43 & Fragaria nubicola & Mehwa & 30 & $75 \%$ \\
\hline 44 & Geranium rotundifolium & Ratan jut & 11 & $27 \%$ \\
\hline 45 & Geranium villosum & Gull-e-attar & 8 & $20 \%$ \\
\hline 46 & Gerbera gossypina & Kofe & 10 & $25 \%$ \\
\hline 47 & Hylotelephium ewersii & Loon salooni & 6 & $15 \%$ \\
\hline 48 & Ilex dipyrena & Kandaro & 2 & $5 \%$ \\
\hline 49 & Indigofera heterantha & Kanthi & 13 & $32 \%$ \\
\hline 50 & Isodon rugosus & Pemar & 21 & $52 \%$ \\
\hline 51 & Juncus arcuatus & Jungli ghass & 11 & $27 \%$ \\
\hline 52 & Juniperus communis & Bentheri & 4 & $10 \%$ \\
\hline 53 & Lespedeza juncea & Kanthi ranga & 9 & $22 \%$ \\
\hline
\end{tabular}




\begin{tabular}{|l|l|l|l|l|}
\hline 54 & Ligularia thomsonii & Jungli surajmuk & 14 & $35 \%$ \\
\hline 55 & Mentha longifolia & Pahari podina & 29 & $72 \%$ \\
\hline 56 & Matricaria chamomilla & Tamak boti & 20 & $50 \%$ \\
\hline 57 & Morina persica & Bekh-e-Akwar & 8 & $20 \%$ \\
\hline 58 & Meliosma simplicifolia & Bakhaish & 5 & $12 \%$ \\
\hline 59 & Oxalis corniculata & Khatimli & 24 & $60 \%$ \\
\hline 60 & Onychium japonicum & Kangu & 2 & $5 \%$ \\
\hline 61 & Oxyria digyna & Kakri & 10 & $25 \%$ \\
\hline 62 & Onosma bracteata & Gao zuban & 4 & $10 \%$ \\
\hline 63 & Origanum vulgare & Nazbu & 9 & $22 \%$ \\
\hline 64 & Polygala chinensis & Sanp ki jari & 10 & $25 \%$ \\
\hline 65 & Phlomis bracteosa & Kukarjari & 16 & $40 \%$ \\
\hline 66 & Pedicularis brevifolia & Khasturi & 14 & $35 \%$ \\
\hline 67 & Primula denticulata & Mamera & 3 & $7 \%$ \\
\hline 68 & Podophyllum hexandrum & Ban kukri & 12 & $30 \%$ \\
\hline 69 & Populus alba & Sufaida & 18 & $45 \%$ \\
\hline 70 & Plantago lanceolata & Kala chamchi patr & 25 & $62 \%$ \\
\hline 71 & Persicaria mitis & Pahari masloon & 13 & $32 \%$ \\
\hline 72 & Picea smithiana & Kachal & 10 & $25 \%$ \\
\hline 73 & Podophyllum emodi & Tra patra & 10 & $25 \%$ \\
\hline 74 & Pinus wallichiana & Kayal & 23 & $57 \%$ \\
\hline 75 & Pinus roxburghii & Cheer & 23 & $57 \%$ \\
\hline 76 & Rosa macrophylla & Shigari & 29 & $72 \%$ \\
\hline 77 & Rheum emodi & Chit patra & 7 & $17 \%$ \\
\hline 78 & Rubus niveus & Pakana & 18 & $45 \%$ \\
\hline 79 & Rheum australe & Chutyal & 11 & $27 \%$ \\
\hline 80 & Rhus succedanea & 7 & $17 \%$ \\
\hline
\end{tabular}




\begin{tabular}{|l|l|l|l|l|}
\hline 81 & Saussurea lappa & Kuth & 20 & $50 \%$ \\
\hline 82 & Silene vulgaris & Murkun & 24 & $60 \%$ \\
\hline 83 & Sonchus asper & Dhodal & 20 & $50 \%$ \\
\hline 84 & Sorghum halepense & Baru & 1 & $2 \%$ \\
\hline 85 & Senecio chrysanthemoides & Chir hand & 14 & $35 \%$ \\
\hline 86 & Skimmia laureola & Neri & 21 & $52 \%$ \\
\hline 87 & Salix tetrasperma & Bheens & 4 & $10 \%$ \\
\hline 88 & Symplocos paniculata & Ludder & 1 & $2 \%$ \\
\hline 89 & Sarcococca saligna & Shangal & 5 & $12 \%$ \\
\hline 90 & Satyrium nepalense & Tera Kanna & 4 & $10 \%$ \\
\hline 91 & Scutellaria linearis & Birch & 9 & $22 \%$ \\
\hline 92 & Swertia paniculata & Charyta & 2 & $5 \%$ \\
\hline 93 & Solidago capitata & Pinja phool & 7 & $17 \%$ \\
\hline 94 & Thymus linearis & Ban jamani & 19 & $47 \%$ \\
\hline 95 & Taxus baccata & Thuni & 6 & $15 \%$ \\
\hline 96 & Trifolium repens & Sinja & 21 & $52 \%$ \\
\hline 97 & Viola biflora & Phul naqsh & 12 & $30 \%$ \\
\hline 98 & Vicia sativa & Chiri pancha & 17 & $42 \%$ \\
\hline 99 & Viburnum cotinifolium & Ukloo & 14 & $35 \%$ \\
\hline 100 & Viscum album & ---------- & 11 & $27 \%$ \\
\hline 101 & Valeriana jatamansi & Panchi hola & 16 & $40 \%$ \\
\hline 102 & Viola canescens & Thandi jari & 15 & $37 \%$ \\
\hline 103 & Wulfenia amherstiana & --------- & 3 & $7 \%$ \\
\hline
\end{tabular}

Family with highest numner of plant species, number of species contained in each family and family ranking (FR) explored from the study area (Table 9). It was observed that highest FR was shown Asteraceae and lowest FR indicated by Rosaceae. These findings were very closely supported by Maqbool and his colleagues [30].

Table 9 Measurement of Family index (with highest number of species) in the study area 


\begin{tabular}{|l|l|c|c|}
\hline S. No. & Family & Number of species & Ranking \\
\hline 1 & Asteraceae & 12 & 1 st \\
\hline 2 & Lamiaceae & 10 & 2 nd \\
\hline 3 & Polygonaceae & 7 & 3 rd \\
\hline 4 & Papilionaceae & 6 & 4 th \\
\hline 5 & Pinaceae & 5 & 5 th \\
\hline 6 & Poaceae & 4 & 6th \\
\hline 7 & Rosaceae & 4 & 7 th \\
\hline
\end{tabular}

Spearman's rank correlation test confirmed that the number of uses of plants increases with increases in the number of species. In spearman's correlation, we correlated the indigenous knowledge of males and females to find out the facts that either the females have better knowledge as compared to males or not as well as we also correlated the number of uses with the number of plants (Table 10,11, 12). Similar studies were conducted by Ahmad and his colleages [24] in Kel, Neelum Valley Azad Jammu and Kashmir and Amjad and his colleages were also done work in Toli Peer National Park, Azad Jammu and Kashmir. They were investigated plant species from their respected areas and applied statistical tools such as FL, ICF, DMR and FI [28]. Similar statistical tools were also applied by Maqbool et al., 2019 on ethnobotanical data compiled from district Bhimber, Azad Jammu and Kashmir, Pakistan [30].

Table 10 Spearman's rank correlation and data analysis from Dawarian to Rati Gali, AJK

\begin{tabular}{|l|c|c|c|}
\hline Age range & Number of interviews & Male informants & Female informants \\
\hline $20-29$ & 13 & 2 & 11 \\
\hline $30-39$ & 2 & 1 & 1 \\
\hline $40-49$ & 8 & 6 & 2 \\
\hline $50-59$ & 4 & 3 & 1 \\
\hline $60-69$ & 5 & 1 & 3 \\
\hline $70-79$ & 3 & 0 & 1 \\
\hline $80-89$ & 3 & 2 & 0 \\
\hline $90-99$ & 2 & 1 & \\
\hline
\end{tabular}


Table 11 Spearman correlation for male informants in study area

\begin{tabular}{|l|c|l|c|l|c|l|}
\hline Age & Number of species & $d 1$ & Number of uses & $d 2$ & $d=d 2-d 1$ & $d^{2}$ \\
\hline 25 & 14 & 5 & 16 & 5 & 0 & 0 \\
\hline 35 & 9 & 2 & 4 & 1 & -1 & 1 \\
\hline 44 & 16 & 6 & 28 & 7 & 1 & 1 \\
\hline 55 & 12 & 4 & 11 & 3 & -1 & 1 \\
\hline 66 & 7 & 1 & 10 & 2 & 1 & 1 \\
\hline 85 & 18 & 7 & 20 & 6 & -1 & 1 \\
\hline 94 & 10 & 3 & 13 & 4 & 1 & 1 \\
\hline
\end{tabular}

Sum of value of $d^{2}=6$

$r_{s}=1-6\left[\frac{\sum d^{2}}{n\left(n^{2}-1\right)}\right] ; r_{s}=1-6\left[\frac{6}{7\left(7^{2}-1\right)}\right] ; r_{s}=1-6\left[\frac{6}{7(49-1)}\right], r_{s}=1-6\left[\frac{6}{7(48)}\right] ; r_{s}=1-6$

$\left[\frac{6}{336}\right] ; r_{s}=1-6[0.01] ; r_{s}=1-0.06 ; r_{s}=0.9$

Table 12 Spearman correlation for female informants in study area

\begin{tabular}{|l|c|l|c|l|c|l|}
\hline Age & Number of species & $\mathrm{d} 1$ & Number of uses & $\mathrm{d} 2$ & $d=d 2-d 1$ & $d^{2}$ \\
\hline 24 & 11 & 2 & 13 & 1 & -1 & 1 \\
\hline 35 & 14 & 5 & 18 & 4 & -1 & 1 \\
\hline 45 & 18 & 7 & 20 & 6 & -1 & 1 \\
\hline 54 & 10 & 1 & 15 & 2 & 1 & 1 \\
\hline 65 & 12 & 3 & 16 & 3 & 0 & 0 \\
\hline 75 & 13 & 4 & 19 & 5 & 1 & 1 \\
\hline 84 & 15 & 6 & 22 & 7 & 1 & 1 \\
\hline
\end{tabular}

Sum of value of $d^{2}=6$

$r_{S}=1-6\left[\frac{\sum d^{2}}{n\left(n^{2}-1\right)}\right] ; r_{S}=1-6\left[\frac{6}{7\left(7^{2}-1\right)}\right] ; r_{S}=1-6\left[\frac{6}{7(49-1)}\right] ; r_{s}=1-6\left[\frac{6}{7(48)}\right] ; r_{s}=1-6$

$\left[\frac{6}{336}\right] ; r_{s}=1-6[0.01] ; r_{s}=1-0.06 ; r_{s}=0.9$

Informant consensus factor (ICF) was used to support the data and to see the degree of agreement on each plant reported by informants (Table 13A). The highest value of ICF is 0.91 for earache who depict prevalence of diseases mostly in children in the area and for construction houses because people in study area only depends on tree for construction their houses. The lowest 
value is for fodder 0.03 (Table 13B). Similar findings were correlated and strongly supported by Farooq and his colleages [26]. Maximum informant consensus factor (0.88) was calculated for digestive and liver disorders (Table 13B). According to diseases vise ICF was also measured by different sciencists in rest of the world [30].

Table 13A Informant consensus factor (ICF) for different categories (For diseases)

\begin{tabular}{|c|c|c|c|c|c|}
\hline Diseases & $\begin{array}{l}\text { Species } \\
\text { (nt) }\end{array}$ & All spp. \% & $\begin{array}{l}\text { Used } \\
\text { citation } \\
\text { (nur) }\end{array}$ & All citation \% & $\mathbf{I C F}=\frac{(\text { nur }-\mathrm{nt})}{(\text { nur }-1)}$ \\
\hline Cough & 13 & $12.7 \%$ & 26 & $65 \%$ & 0.52 \\
\hline Stomachache & 11 & $10.6 \%$ & 30 & $75 \%$ & 0.65 \\
\hline Asthma & 10 & $9.70 \%$ & 20 & $50 \%$ & 0.52 \\
\hline Wounds healing & 9 & $8.73 \%$ & 14 & $35 \%$ & 0.33 \\
\hline Joint pain & 7 & $6.79 \%$ & 22 & $55 \%$ & 0.71 \\
\hline Toothache & 7 & $6.79 \%$ & 25 & $62 \%$ & 0.75 \\
\hline Fever & 5 & $4.85 \%$ & 19 & $47 \%$ & 0.77 \\
\hline Chest burning & 5 & $4.85 \%$ & 10 & $25 \%$ & 0.55 \\
\hline Dysentery & 4 & $3.88 \%$ & 5 & $12 \%$ & 0.25 \\
\hline Muscle pain & 4 & $3.88 \%$ & 12 & $30 \%$ & 0.72 \\
\hline Eye allergy & 4 & $3.88 \%$ & 15 & $37 \%$ & 0.78 \\
\hline Blood purification & 4 & $3.88 \%$ & 7 & $17 \%$ & 0.5 \\
\hline Constipation & 3 & $2.91 \%$ & 6 & $15 \%$ & 0.6 \\
\hline Headache & 3 & $2.91 \%$ & 18 & $45 \%$ & 0.88 \\
\hline Flu & 3 & $2.91 \%$ & 11 & $27 \%$ & 0.8 \\
\hline Skin allergy & 3 & $2.91 \%$ & 2 & $5 \%$ & 0.25 \\
\hline Cold & 2 & $1.94 \%$ & 9 & $22 \%$ & 0.87 \\
\hline Earache & 2 & $1.94 \%$ & 13 & $32 \%$ & 0.91 \\
\hline Diarrhea & 2 & $1.94 \%$ & 6 & $15 \%$ & 0.8 \\
\hline
\end{tabular}

Table 13B Informant consensus factor (ICF) for different categories (For other purposes) 


\begin{tabular}{|l|l|l|l|l|l|}
\hline Category & $\begin{array}{l}\text { Species } \\
\text { (nt) }\end{array}$ & All spp. \% & $\begin{array}{l}\text { Used } \\
\text { citation } \\
(\text { nur })\end{array}$ & $\begin{array}{l}\text { All citation } \\
\%\end{array}$ & ICF= $\frac{(\text { nur-nt })}{(\text { nur-1) }}$ \\
\hline Fodder & 28 & $27.9 \%$ & 29 & $72 \%$ & 0.03 \\
\hline Food & 24 & $23.3 \%$ & 35 & $87 \%$ & 0.32 \\
\hline Fuel & 13 & $12.6 \%$ & 32 & $80 \%$ & 0.61 \\
\hline Furniture & 5 & $4.94 \%$ & 34 & $85 \%$ & 0.87 \\
\hline Construction & 5 & $4.94 \%$ & 39 & $97 \%$ & 0.89 \\
\hline House Thatching & 4 & $3.88 \%$ & 36 & $90 \%$ & 0.91 \\
\hline
\end{tabular}


Table 14 Direct matrix ranking (DMR) of tree species with different uses other than medicinal value in the study area (AJK)

\begin{tabular}{|l|l|l|l|l|l|l|l|l|}
\hline & $\begin{array}{l}P . \\
\text { wallichiana }\end{array}$ & $\begin{array}{l}\boldsymbol{P} . \\
\text { roxburghii }\end{array}$ & $\begin{array}{l}P . \\
\text { smithiana }\end{array}$ & $\begin{array}{l}\text { C. } \\
\text { deodara }\end{array}$ & $\begin{array}{l}\text { A. } \\
\text { pindrow }\end{array}$ & $\begin{array}{l}\text { A. } \\
\text { cappadocicum }\end{array}$ & $\begin{array}{l}P . \\
\text { alba }\end{array}$ & $\begin{array}{l}\text { S. } \\
\text { tetrasperma }\end{array}$ \\
\hline Construction & 40 & 40 & 35 & 36 & 30 & 0 & 0 & 0 \\
\hline $\begin{array}{l}\text { Hedge, } \\
\text { Fencing }\end{array}$ & 20 & 18 & 15 & 10 & 15 & 14 & 20 & 22 \\
\hline Fire wood & 25 & 29 & 35 & 38 & 30 & 32 & 28 & 19 \\
\hline $\begin{array}{l}\text { Cash } \\
\text { income }\end{array}$ & 40 & 38 & 30 & 35 & 20 & 0 & 2 & 0 \\
\hline Fodder & 5 & 2 & 8 & 4 & 10 & 20 & 22 & 29 \\
\hline Fruit, Food & 0 & 0 & 0 & 5 & 0 & 0 & 0 & 0 \\
\hline Total & 130 & 127 & 123 & 128 & 105 & 66 & 72 & 70 \\
\hline Rank & 15 & 3 rd & $4^{\text {th }}$ & 2 nd & 5 th & $8^{\text {th }}$ & 6 th & 7 th \\
\hline
\end{tabular}

According to Direct matrix ranking (DMR), plant species were also used for other purposes than medicinal values as indicated in Table 14. These results indicated that the plant species $P$. wlllichiana top of the list with DMR $1^{\text {st }}(130)$. While S. tetrasperma indicated $2^{\text {nd }}$ position according to other use value. These findings were strongly justified by different taxonomists. They calculated DMR from various regions of the world as strongly correlated with our studies [35-40].

Thus, the study is very useful as it provide baseline data compilation about tradiotnal ethnomedicinal uses of wild plants of the area and it also describes the biotic threats to the flora of the area. Through this study important and unqiue medicinal plants are selected for futher studies to comfirm their ethnopharmacological analysis and drug discovery. 


\section{Conclusion}

The present research focused to explored the uses of plants in different purposes by experience of old peoples in the study area. ethnobotanical research focused to explored the uses of plants in different purposes by experience of old peoples in the study area. Ethnobotanical survey on the unexplored areas of District Anthmaqam, Azad Jummu \& Kashmir were selected for identification of wild plants and their ethnomedical impacts exploration. This research was carried out by interviewing the local peoples through a questionnaire method. Data analysis was done by different novel statistical tools such as fidelity level (FL), informant consensus factor (ICF), direct matrix ranking (DMR) strategies. Some plants were used as medicines only for indigenous peoples continuesly and we reccomented these plants for peoples in other parts of countery as well as throughout the world in future. It was observed that peoples used plants as vegetables, fodder, fuel, timber and as well as for medicinal purposes. Local peoples are using many types of indrgenous wild plants to cure different diseases like asthma, dysentery, constipation, cold, fever, joint pain, wound healing, kidney infection and many types of skin diseases. A total of 103 plants species belonging to 46 families were recorded. The most dominant family of that area was Asteraceae having 12 species. Among 103 plants $75.72 \%$ have singleusage, $20.38 \%$ have dual-usages and $3.88 \%$ have multiple-usage. Among plant partused, leaves having the highest percentage $34 \%$ which are commonly used by local people for the treatment of various diseases followed by the root $25.2 \%$. Some plants used as fodder having highest percentage $37 \%$ followed by Food (vegetables and fruits) with 32\%. Data analysis through FL depicted that Allium griffithianum and Adiantum aethiopicum have highest fidelity level of $75 \%$ followed by the Mentha longifolia with fedility level of about $72 \%$. The highest ICF value for recorded for ear-ache and house-thatching (0.91) followed by the construction (0.89) while the lowest ICF value recorded for fodder (0.03) followed by blood purification (0.5). Spearman's rank correlation test confirmed that the number of uses of plants increases with the increase in the number of species. So, this study will be useful those peoples and researchers in different fields such as ethnopharmacology, agriculture and biotechnology for future work.

\section{Acknowledgements}

The work is greatly acknowledging to the peoples of the study area who provided ethnobotanical information for compleyion of this research project. 


\section{Declaration}

An ethnobotanical exploration of naturally growing plants of District Athmaqam from Dawarian to Ratti Gali, Azad Jammu and Kashmir.

\section{Authors' contributions}

MA supervised the project, TH designed the study, conducted field survey and data analysis, MI helped in data interpretation and correction of the final draft of the paper. All the authors critically read this article and approved it as the final manuscript.

\section{Funding}

This paper is a part of a MPhil thesis of a student. However, no funding was provided by any source to conduct this reseach project.

\section{Availability of data and materials}

The data and materials already included in this manuscript.

\section{Ethics approval and consent to participate}

The present ethnomedicinal research is purely based on a field survey instead of human or animal trails. Therefore, ethical approval and consent to participate is not applicable.

\section{Concent of publication}

This manuscript data related to ethnobotanical research is sharing to the journal of ethnobiology and ethnomedicine after concent of all author/coauthor.

\section{Competing interests}

The authors declare that they have no competing interests.

\section{Author details}

Department of Botany, Mirpur University of Science and Technology (MUST), Mirpur - 10250 (AJK) Pakistan

\section{References}

1. Husain ZS, Malik RN, Javaid M, Bibi S. Ethnobotanical properties and uses of medicinal plants of Morgha Biodiversity Park, Rawalpindi. Pak. J. Bot. 2008; 40(5):1897-1911. 
2. Mahmood A, Qureshi RA, Mahmood A, Sangi Y, Shaheen HM, Ahmad I, Nawaz Z. Ethnobotanical survey of common medicinal plants used by people of District Mirpur, AJK, Pakistan. J Medicin Plants Res. 2011;5(18):4493-4498.

3. Shinwari ZK. Medicinal plants research in Pakistan. J Medi Plant Res. 2010;4(3):161-176.

4. Khan MA, Hussain M, Mujtaba G. An Ethnobotanical Inventory of Himalayan Region Poonch Valley Azad Kashmir Pakistan. Ethnobot Res and Applic, 8:107-123.

5. Ibrar M, Hussain, Sultan A. Ethnobotanical studies on plant resources of Ranyal hill, District Shangla, Pakistan. Pak. J. Bot. 2007;39(2):329-337.

6. Ajaib M, Ashraf Z, Riaz F, Siqqidue MF. Ethnobotanical studies of some plants of Tehsil Kharian, District Gujrat. FUUAST J. Biol. 2014;4(1):65-71.

7. Malik RN, Husain, SZ, Nazir I. Heavy metal contaminatiom and accumulation in soil and wild plant species from industrial area of Islamabad. Pak. J. Bot. 2010;42(1):291-301.

8. Prabhu S, Kumar V. Ethanobotanical study of Traditionally Used Medicinal Plants in Malayali Ethnic People of Pachamalai Hills, Tamil Nadu, India. J. Pharma. Medicinal Rese. 2016;2(1):39-42.

9. Tangjang S, Nima D, Chocha A, Anggu L. An ethnobotanical survey of medicinal plants in the Eastern Himalayan zone of Arunachal Pradesh, India. J. ethnopharm. 2010;134:1825.

10. Pardo-de-Santayana M, Tardio J, Blanco E, Carvalho AM, Lastra JJ, Miguel ES. Traditional knowledge of wild edible plants used in the northwest of the lberian Peninsula (Spain and Portugal): a comparative study. J Ethnobiol and Ethnomed. 2007. https://doi.org/10.1186/1746-4269$\underline{3-27}$.

11. Sharma L, Deepika T, Sanjay KU. Plant-derived utility products: knowledge comparison across gender, age and education from a tribal landscape of western Himalaya. J Ethnobiol and Ethnomed. 2019;15:67.

12. Shaikh SH, Malik F, James H, Abdul H. Trends in the use of complementary and alternative medicine in Pakistan: a population-based survey. J Altern Complement Med. 2009;15(5):545-50. 
13. Ahmad KS, Sadaf H. Indigenous Knowledge of Some Medicinal plants of Himalaya Region, Dawarian Village, Neelum Valley, Azad Jammu and Kashmir, Pakistan. U J Plant Sci. 2014;2(2):40-47.

14. Parvaiz M. Ethnobotanical studies on plant resources of Mangowal, District Gujrat, Punjab, Pakistan. J. Phytomed. 2014;5:364-370.

15. Ajaib M, Khan ZUD, Annam Z. Ethnobotanical survey of some important herbaceous plants of District Kotli, Azad Jammu and Kashmir. Biologia (Pak.). 2014;60:11-22.

16. Ajaib M, Musfirah A, Nafeesa ZM Muhammad FS. Ethnobotanical study of some plants of Darguti, Tehsil Khuiratta, Azad Jammu and Kashmir. Int. J. Biol. Res. 2015;3(2):101107.

17. Mahmood, A., Rifat, N. M., Zabta, K. S. and Aqeel, M. Ethnobotanical Survey of plants from Neelum, Azad Jammu \& Kasmir, Pak J Bot. 2011;43: 105-110.

18. Quave CL, Pieroni A. A reservoir of ethnobotanical knowledge informs resilient food security and health strategies in the Balkans. Nature Plants. 2015;1(2):14021.

19. Amjad MS, Arshad M, Qureshi R. Ethnobotanical inventory and folk uses of indigenous plants from Pir Nasoora National Park, Azad Jammu and Kashmir. Asian Pac J Trop Biomed. 2015;5(3):234-41.

20. Ishtiaq CM, Khan M, Hanif W. An ethnomedicinal inventory of plants used for family planning and sex diseases treatment in Samahni valley,(AK) Pakistan. Pak J Biol Sci. 2006;9(14):2546-55.

21. Akbar K. Potential impacts of climate change on plant diversity of hilly areas of Azad Kashmir and their mitigation: a review. J Mt Area Res. 2017; 2:37-44.

22. Ahmad, KS, Qureshi R, Hameed M, Ahmad F, and Nawaz T. Conservation assessment and medicinal importance of some plants resources from Sharda, Neelum valley, Azad Jammu and Kashmir. International J of Agric and Biol. 2012b;14: 997-1000.

23. Dar MEU. Ethnobotanical use of Lawat district Muzaffarabad, Azad Jammu and Kashmir. Asian J of Plant Sci. 2003;2 (9):680-682.

24. Ahmad KS, Abdul H, Fahim N, Mansoor H, Farooq A, Jiabin D, Noreen A, Ambreen W, Sehrish M. Ethnopharmacological studies of indigenous plants in Kel village, Neelum Valley, Azad Kashmir, Pakistan. J Ethnobiol and Ethnomed. 2017;13:68 
25. Thompson, A., Gemma M, Marie K, Jacinta T. Medicinal plant use in two Tiwi Island communities: a qualitative research study. J of Ethnobiol and Ethnomed. 2019;15:40.

26. Farooq A, Muhammad SA, Khalid A, Muhammad A, Muhammad U, Arshad M. Ethnomedicinal knowledge of the rural communities of Dhirkot, Azad Jammu and Kashmir, Pakistan. J Ethnobiol Ethnomed. 2019;15:45.

27. Uniyal SK, Singh K, Jamwal P, Lal B. Traditional use of medicinal plants among the tribal communities of Chhota Bhangal, Western Himalaya. J of Ethnobiol and Ethnomed. 2006;2(1):14.

28. Amjad MS, Mf Q, Ahmad I, Khan SU, Chaudhari SK, Zahid Malik NZ, Shaheen H, Khan AM. Descriptive study of plant resources in the context of the ethnomedicinal relevance of indigenous flora: a case study from Toli Peer National Park, Azad Jammu and Kashmir, Pakistan. PLoS One.2017;12(2):171-896.

29. Cadena-González AL, Marten S, Ida T. Use and valuation of native and introduced medicinal plant species in Campo Hermoso and Zetaquira, Boyacá, Colombia. J Ethnobiol Ethnomed. 2013, 9:23.

30. Maqbool M, Muhammad A, Muhammad I, Shehzad A, Tanveer H. Ethnomedicinal Study of Plants Used in Phytotherapeutics among Indigenous Communities of District Bhimber, Azad Kashmir and Migrants to United Kingdom. Life and Environ Sci. 2019;56 (2): 5776.

31. Sher H, Bussmann RW, Hart R, Boer HJ. Traditional use of medicinal plants among Kalasha, Ismaeli and Sunni groups in Chitral District, Khyber Pakhtunkhwa province Pakistan. J Ethnopharmacol. 2016;188:57-69.

32. Uniyal SK, Sharma V, Jamwal P. Folk medicinal practices in Kangra district of Himachal Pradesh, western Himalaya. Human Eco. 2011;39:479-88.

33. Polat R, Cakilcioglu U, Kaltalioğlu K, Ulusan MD, Türkmen Z. An ethnobotanical study on medicinal plants in Espiye and its surrounding (Giresun-Turkey). J Ethnopharmacol. 2015;163:1-11.

34. Oliver S. The role of traditional medicine practice in primary health care within Aboriginal Australia: a review of the literature. $J$ Ethnobiol Ethnomed. 2013;9(1):46. 
35. Mahmood A, Tabassum A. Ethnomedicinal survey of plants from District Sailkot, Pakistan. J. App. Pharm., 2(3): 212-220 (2011)

36. Qureshi RA, Ghufran MA, Gilani SA. Ethnobotanical studies of selected medicinal plants of Sudhan Gali and Ganga Chotti Hills, district Bagh, Azad Kashmir. Pak. J. Bot. 2007;39(7):2275-2283.

37. Rahman A H, Alam MS, Khan SK, Ahmed F, Islam AKMR, Rahman MM. Taxonomic studies on the family Asteraceae (Compositae) of the Rajshahi division. Res. J Agricul. and Biol Sci. 2009; 4(2), 134-140.

38. Shinwari ZK, Gilani SS. Sustainable harvest of medicinal plants at Bulashbar Nullah, Astore (Northern Pakistan). J Ethnopharm. 2003;84: 289-298.

39. da Silva MG, da Silva RH, Júnior GAD, Guarim-Neto G. Plants used by the rural community of Bananal, Mato Grosso, Brazil: Aspects of popular knowledge. PloS One. 2019;14(1): 210.

40. Reddy KN, Pattanaik C, Reddy CS, Murthy EN, Raju VS. Plants used in traditional handicrafts in north eastern Andhra Pradesh. Indian J Trad Knowled. 2008;7(1):162. 


\section{Figures}

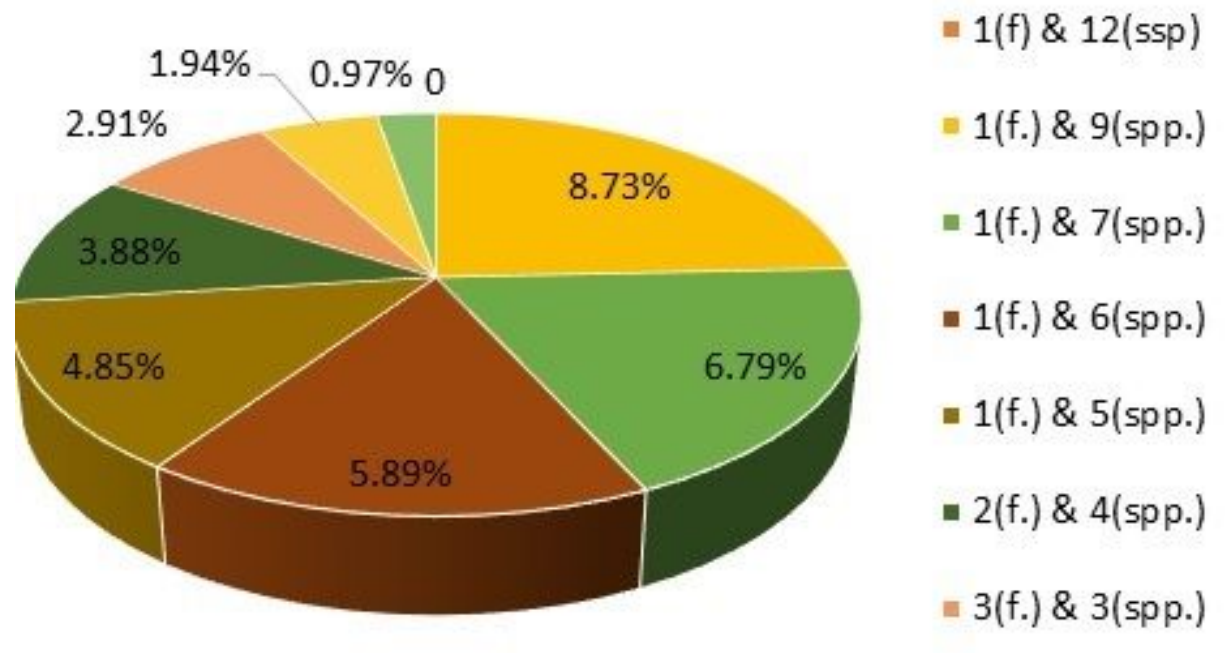

Figure 1

A pie chart of species contribution in each family from study area, Azad Jammu and Kashmir

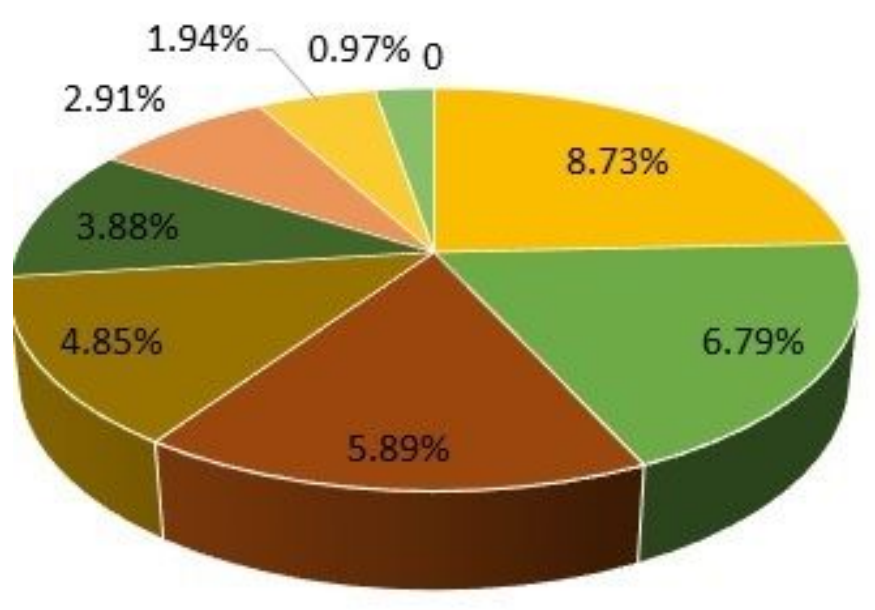

= 1 (f) \& $12(\mathrm{ssp})$

$=1($ f. $) \& 9($ spp. $)$

- 1 (f.) \& 7 (spp.)

- 1 (f.) \& $6($ spp.)

= $1($ f. $) \& 5($ spp. $)$

- $2(\mathrm{f.}) \& 4(\mathrm{spp}$.

$=3(\mathrm{f.}) \& 3(\mathrm{spp}$.

Figure 1

A pie chart of species contribution in each family from study area, Azad Jammu and Kashmir 


\section{Usage of plants}

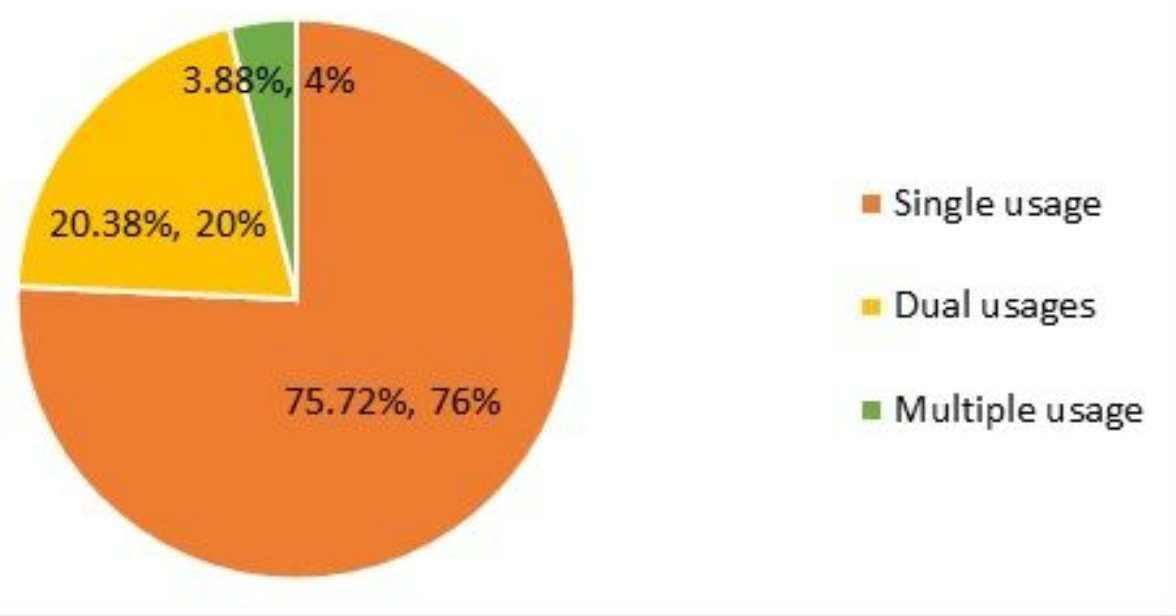

\section{Figure 2}

Graphical presentation of plants on the basis of their usage

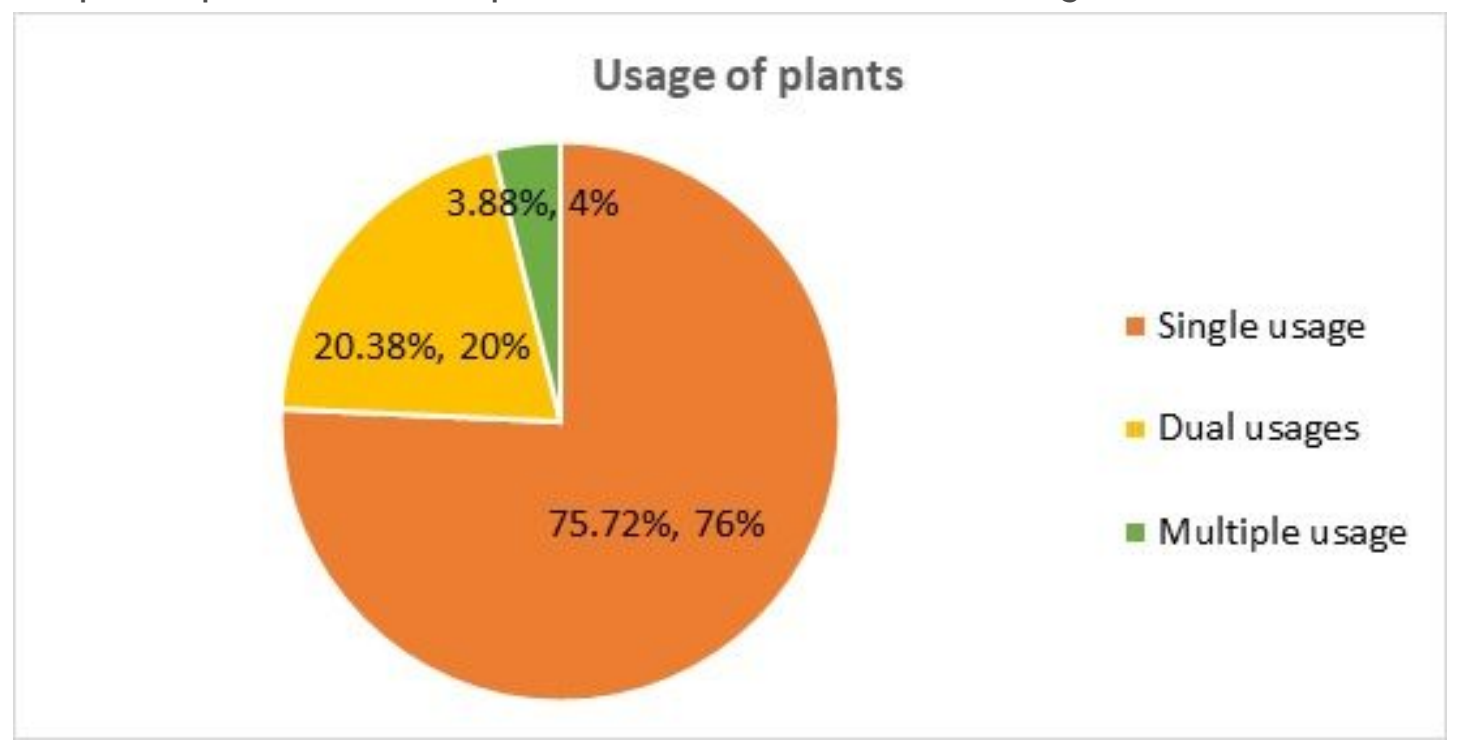

\section{Figure 2}

Graphical presentation of plants on the basis of their usage 


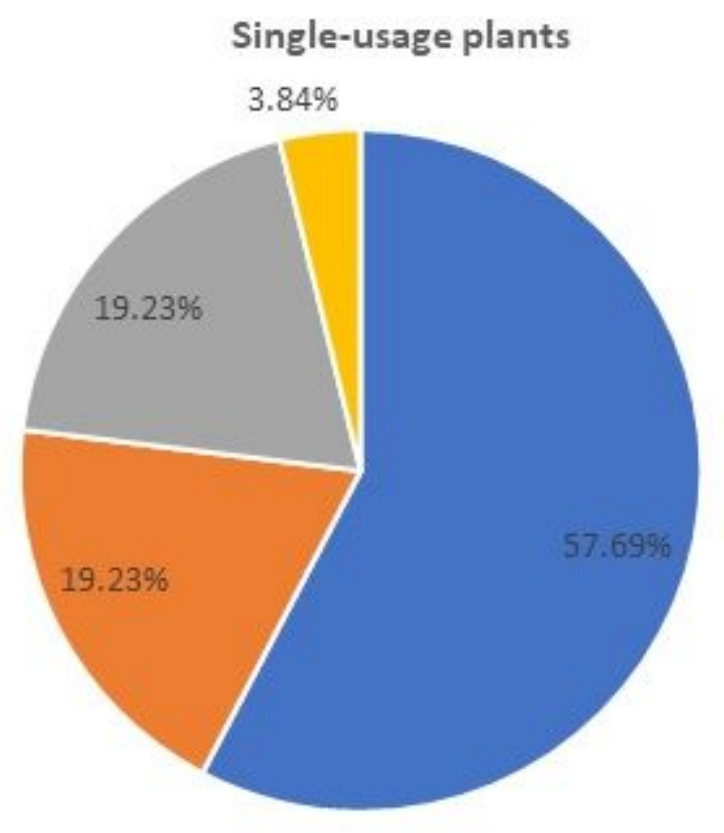

- Medicinal

- Food

- Fodder

- Fuel

\section{Figure 3}

A pie-chart of single-usage plants

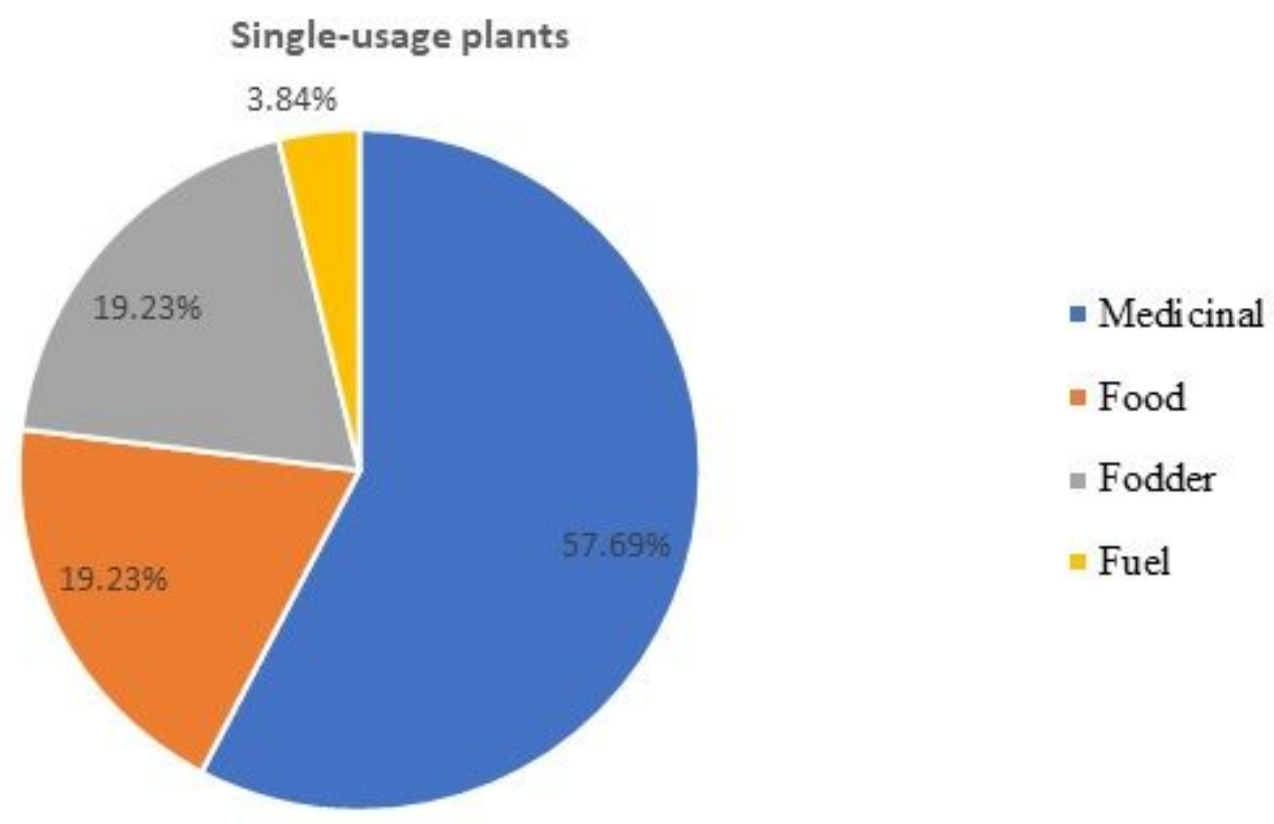

Figure 3

A pie-chart of single-usage plants 


\section{Dual-usage plants \%}

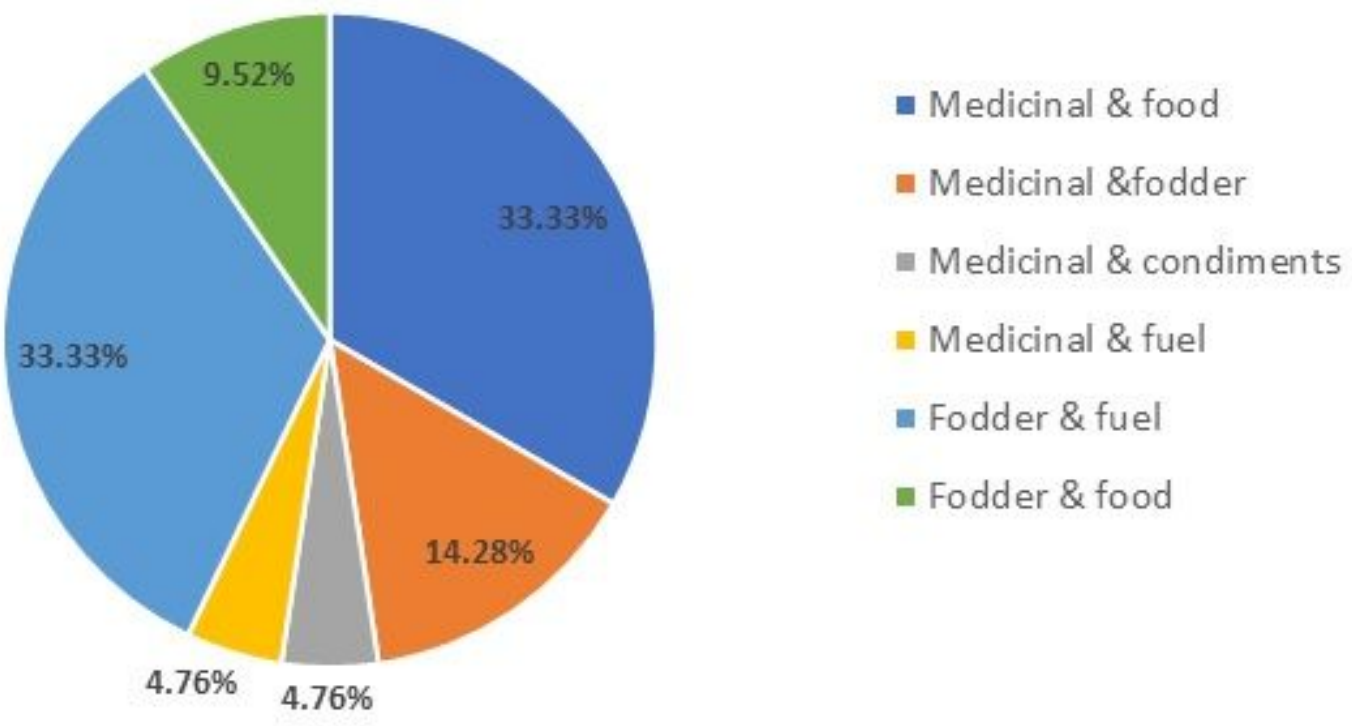

Figure 4

A pie-chart of dual usage plants

\section{Dual-usage plants \%}

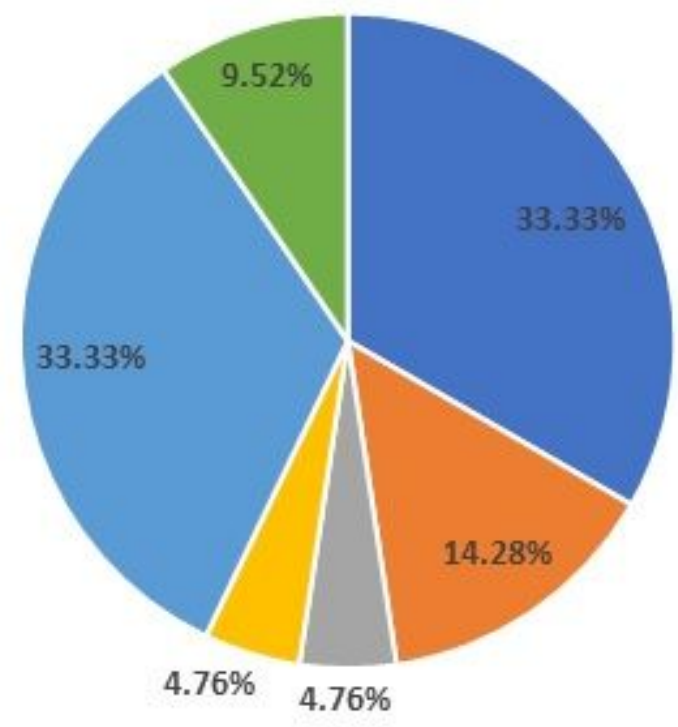

- Medicinal \& food

- Medicinal \&fodder

- Medicinal \& condiments

nedicinal \& fuel

- Fodder \& fuel

- Fodder \& food

\section{Figure 4}

A pie-chart of dual usage plants 


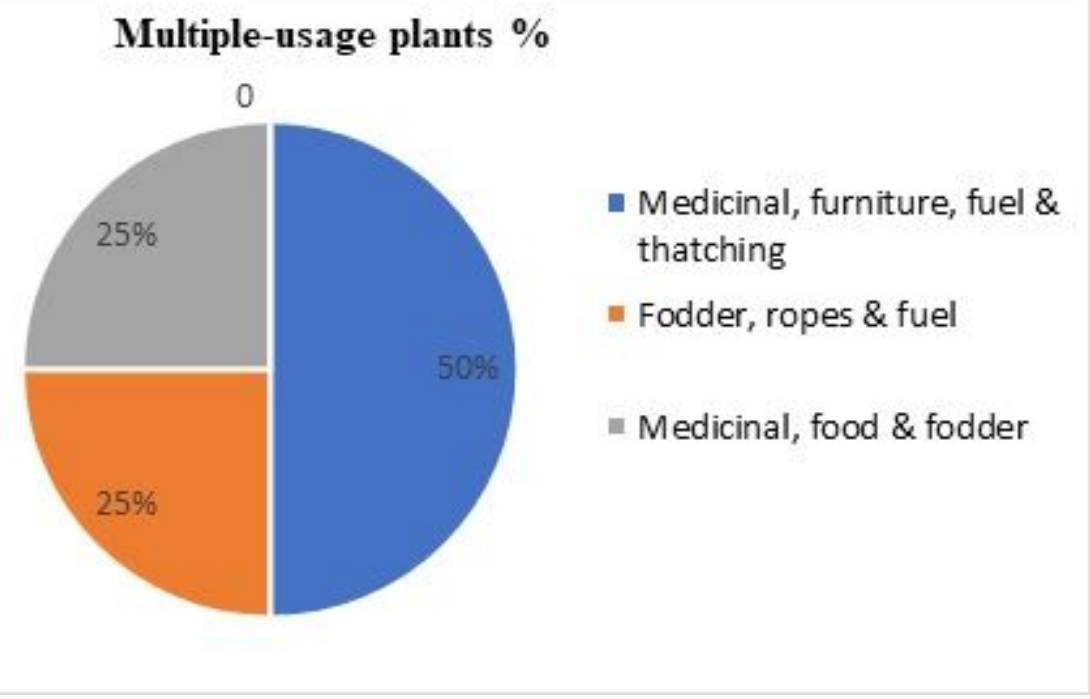

Figure 5

A pie chart of multiple-usage plants

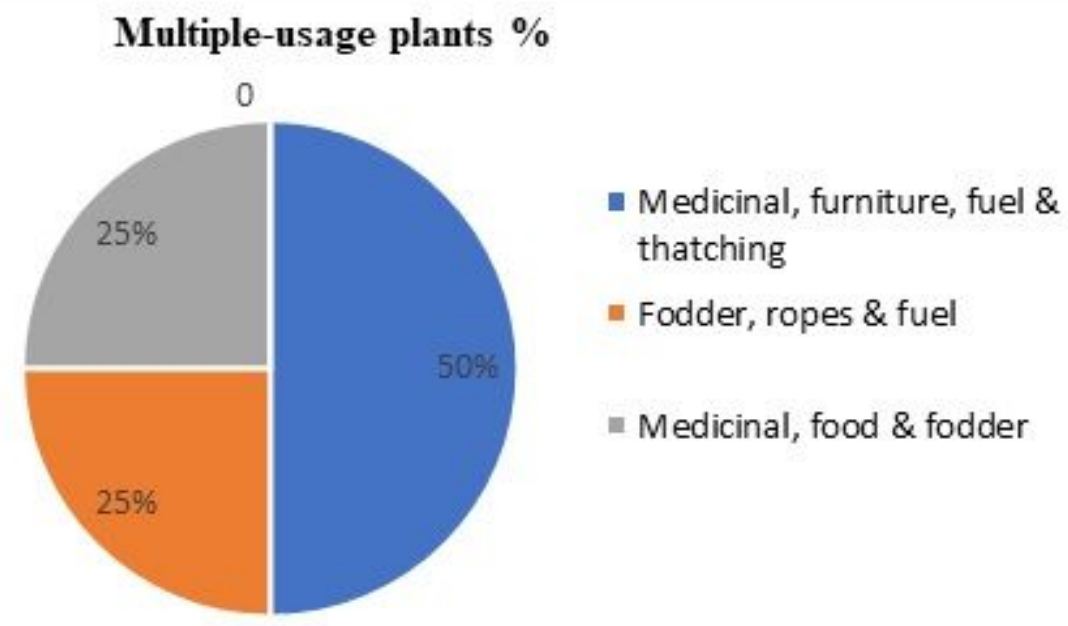

Figure 5

A pie chart of multiple-usage plants 


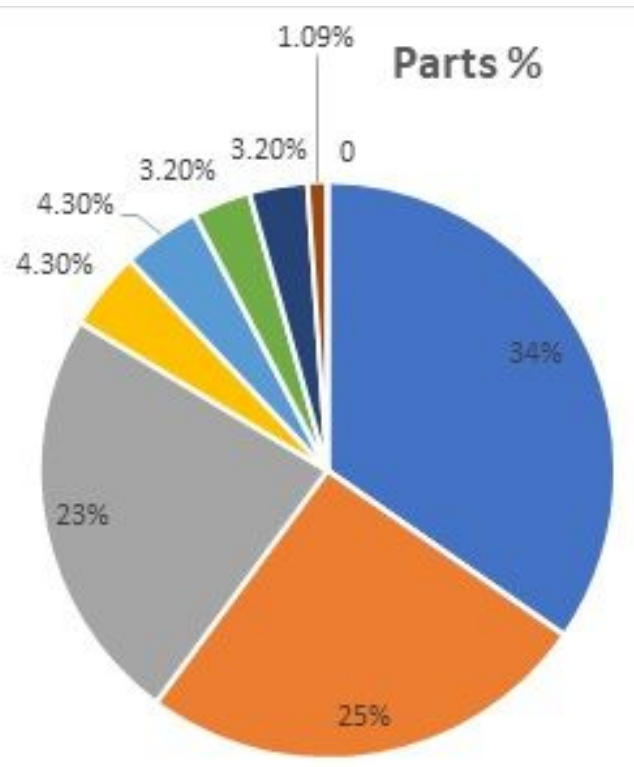

- Leaves

- Roots

- Whole plants

- Stem

- Flower

- Shoot

- Tuber

- Fruit

- Sap

\section{Figure 6}

A pie-chat of different parts of plants used for the treatment of different diseases

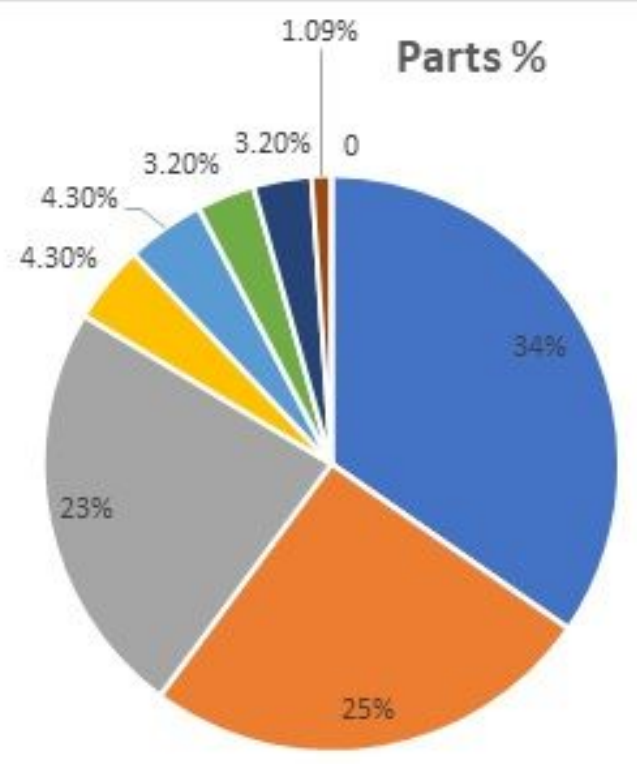

- Leaves

- Roots

- Whole plants

= Stem

- Flower

- Shoot

- Tuber

- Fruit

- Sap

\section{Figure 6}

A pie-chat of different parts of plants used for the treatment of different diseases 


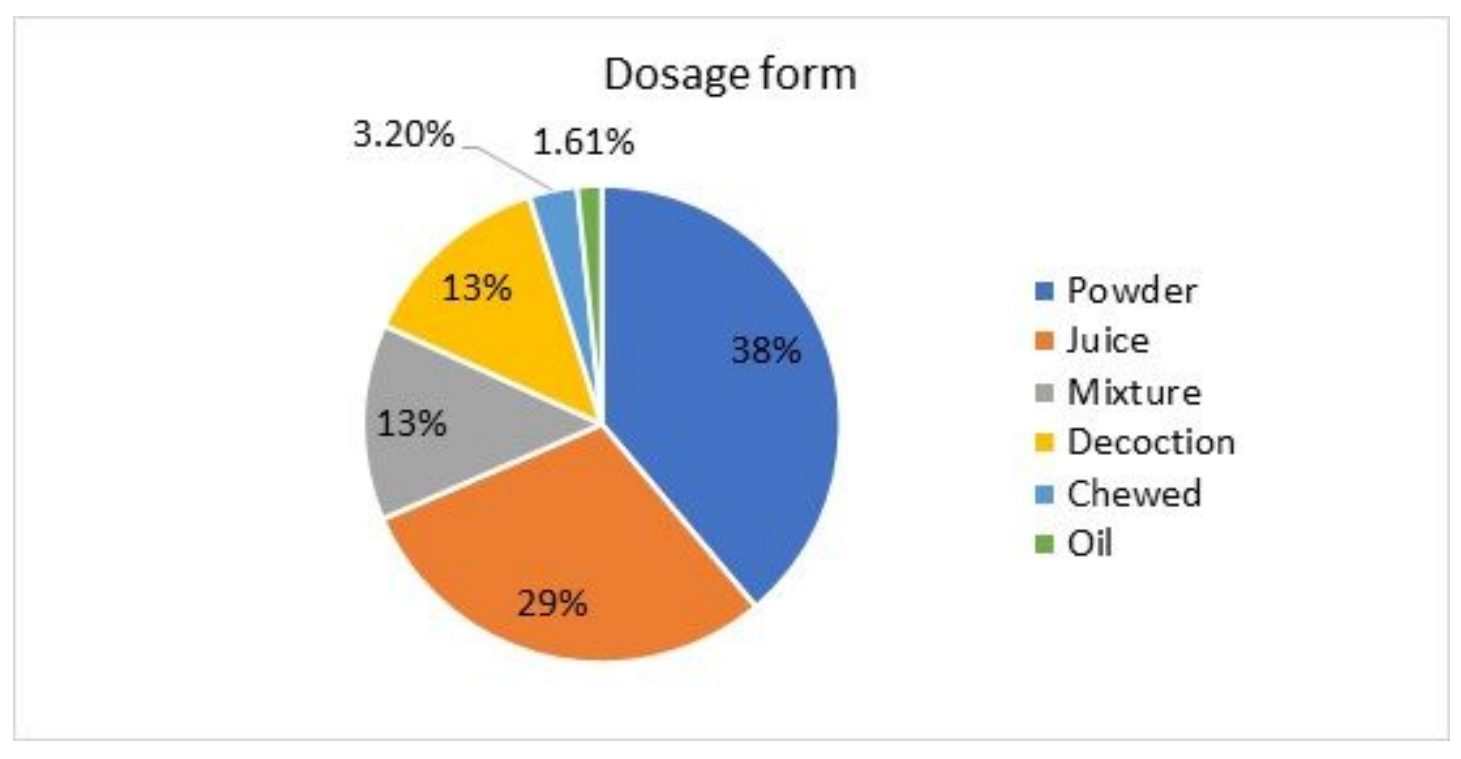

Figure 7

A pie chart of Dosage form used against diseases

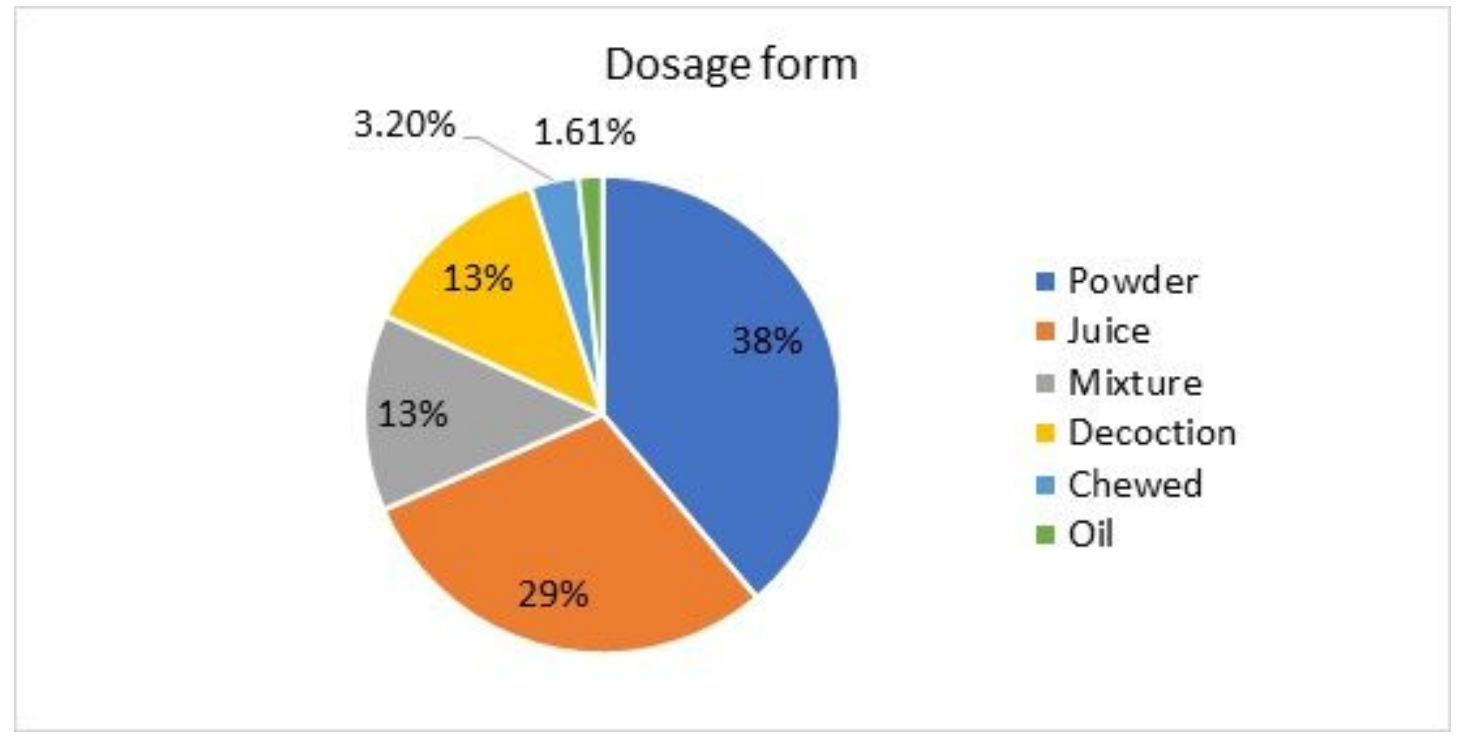

Figure 7

A pie chart of Dosage form used against diseases 


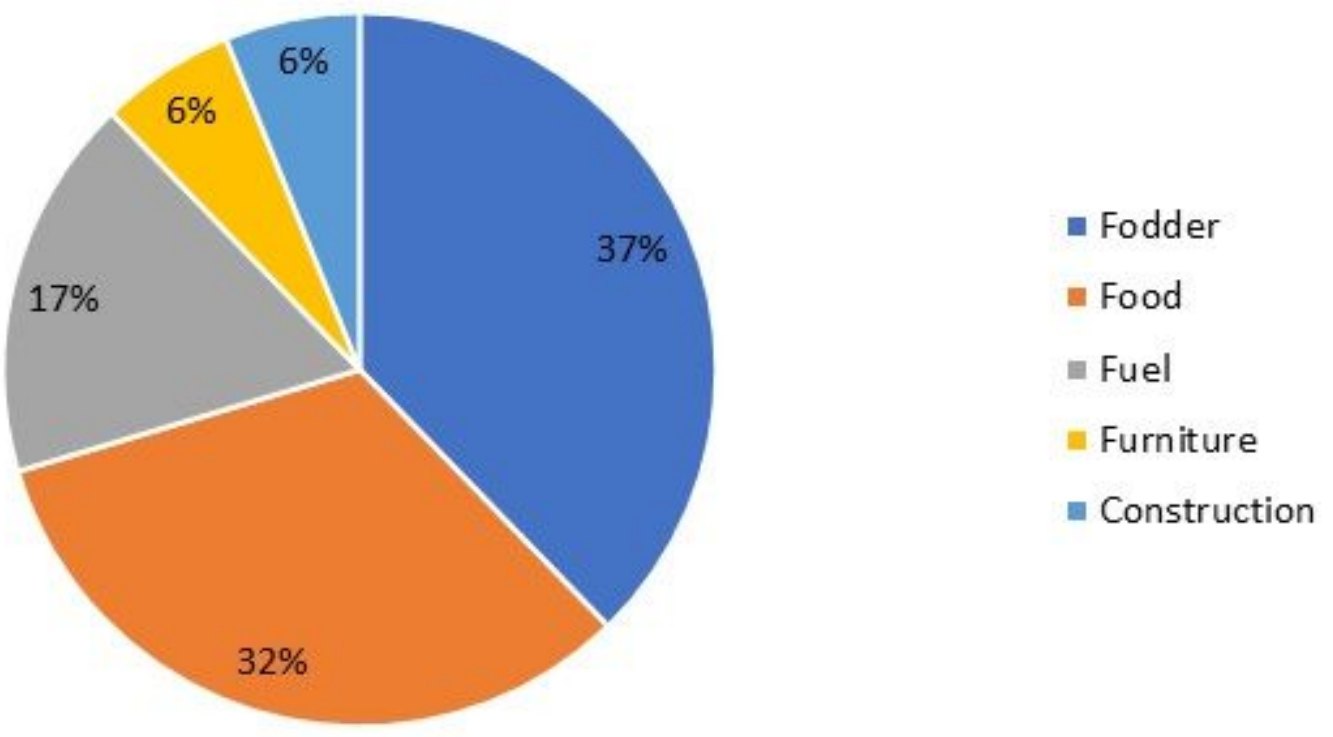

Figure 8

A Pie chart of different plants used by local people in different categories

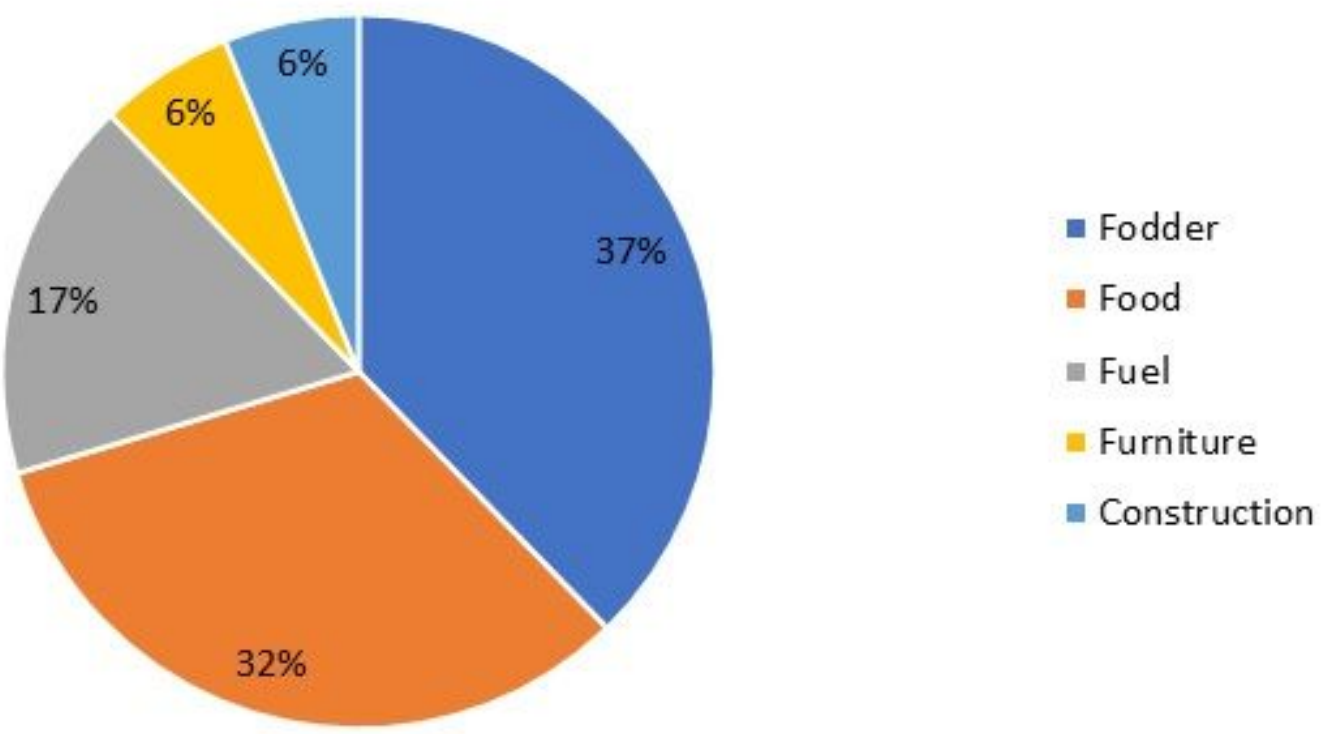

Figure 8

A Pie chart of different plants used by local people in different categories

\section{Supplementary Files}


This is a list of supplementary files associated with this preprint. Click to download.

- suppl1.JPG

- suppl1.JPG 